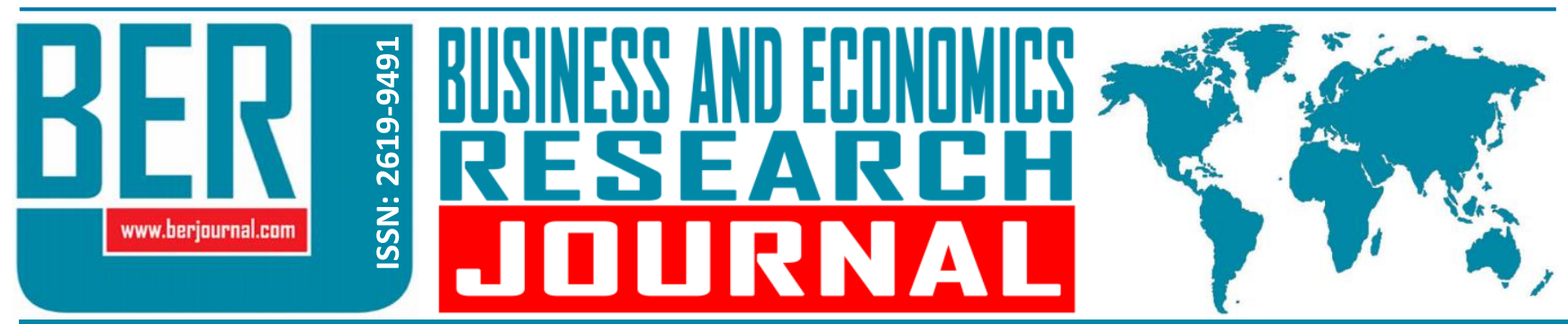

Business and Economics Research Journal Vol. 11, No. 4, 2020, pp. 1049-1067 doi: 10.20409/berj.2020.298

\section{İnovasyon ve Lojistik Boyutları Arasındaki İlişkiye Yönelik Ampirik Bir Araştırma}

\author{
Furkan Fahri Altintas ${ }^{\mathrm{a}}$
}

Öz: Ülkeler inovasyon ve lojistik boyutlarını bir bütün halinde değerlendirdiğinde ve söz konusu boyutların birbirlerini tamamlayacak faaliyetler gerçekleştirdiğinde, ülkeler inovasyon ve lojistik alanında uzmanlaşabilecek ve buna bağlı olarak inovasyon ve lojistik boyutlarının gelişimini küresel anlamda sağlayabileceklerdir. Bu kapsamda araştırmada dünyadaki küresel zenginliğin yarısından fazlasına sahip olan ve belirli bir ekonomik gelişmişliği ile büyüklüğü bulunan G7 ülkelerinin küresel inovasyon ve lojistik performans değerleri kapsamında inovasyon ve lojistik boyutu arasındaki ilişkiler çok boyutlu olarak değerlendirilmiştir. Bulgulara göre, genel anlamda inovasyon ve lojistik boyutları arasında anlamlı, pozitif yönlü ve çok yüksek düzeyde ilişkinin olduğu tespit edilmiştir. Inovasyon ve lojistik boyutlarının birbirleri arasındaki ilişkinin çok yüksek düzeyde çıkması, G7 ülkelerinin ekonomik büyüklüğe, gelişmişliğe ve küresel zenginliğe sahip olmasındaki etkenlerden veya sebeplerden biri olduğu değerlendirilmiştir. Yine bulgulara göre, inovasyon ve lojistik boyutu arasındaki ilişkiye inovasyon boyutu lojistik boyutuna göre daha fazla katkı sağladığı sonucuna ulaşılmıştır. Dolayısıyla söz konusu ülkeler, inovasyon ve lojistik boyutları arasındaki ilişkinin sağlanmasında inovasyon boyutuna daha çok önem verdiği değerlendirilmiştir.

\section{An Empirical Research on the Relationship Between Innovation and Logistics Dimensions}

Abstract: When countries evaluate innovation and logistics as a whole and carry out activities to complement each other, countries will be able to specialize in the field of innovation and logistics and, accordingly, ensure the development of innovation and logistics dimensions globally. In this context, in research, the relations between the innovation and logistics dimensions within the scope of the global innovation and logistics performance values of G-7 countries, which have more than half of the global wealth in the world and have a certain economic development and size, were evaluated in multi-dimensional terms. According to the findings, it is determined that there is a significant, positive, and very highlevel relationship between innovation and logistics dimensions. The fact that the relationship between innovation and logistics is very high has been evaluated as one of the factors or reasons that G7 countries have economic size, development, and global wealth. Again, according to the findings, it was concluded that the innovation dimension contributed more to the relationship between innovation and logistics dimension than the logistics dimension. Therefore, it is considered that these countries place more importance on the innovation dimension in ensuring the relationship between innovation and logistics dimensions.
Anahtar Sözcükler:

İnovasyon, Lojistik, Küresel Inovasyon Endeksi, Lojistik Performans Endeksi, İlişki

JEL: O50, O30, L87

$\begin{array}{ll}\text { Geliş } & : 02 \text { Haziran } 2020 \\ \text { Düzeltme } & : \text { 28 Ağustos } 2020 \\ \text { Kabul } & : \text { : } 11 \text { Eylül } 2020 \\ \text { Tür } & : \text { Araştırma }\end{array}$

Keywords: Innovation, Logistics, Global Innovation Index, Logistics Performance Index, Relationship

JEL: O50, O30, L87 


\section{Giriş}

Inovasyon ve lojistik boyutları birbirleri arasında karşılıklı olarak pozitif yönlü ilişkiye sahiptirler (Olavarrieta ve Ellinger, 1997). Dolayısıyla inovasyon ve lojistik boyutları birbirlerini tamamlayıcı özellikleri bulunmaktadır. Bu durum, inovasyon ve lojistik boyutlarının bir bütün olarak değerlendirilebileceğini göstermektedir. Çünkü söz konusu her iki boyut birbirlerinden faydalanarak birbirlerinin gelişimini sağlamaktadırlar.

Küreselleşmenin etkisi ile birlikte küresel ticaretin ve ekonominin kıymetlenmesi, ülkelerin inovasyon ve lojistik performanslarının tespitinin gereksinim duyulmasını sağlamıştır. Çünkü ülkeler, inovasyon ve lojistik konusundaki eksikliklerini ve geliştirilmesi gereken konuları tespit ederek sonraki süreçlerdeki inovasyon ve lojistik stratejilerini, yöntemlerini, yönetimlerini ve uygulamalarını daha etkin, etkili ve verimli olarak sağlayabilmektedirler. Aynı şekilde ülkeler, birbirlerinin inovasyon ve lojistik konularındaki kapasitelerini, potansiyellerini, üstünlüklerini ve yeteneklerini takip ederek kendilerinin inovasyon ve lojistik konularında daha sağlıklı performans sağlamaları için birbirleri ile inovasyon ve lojistik konularında işbirlikleri ve ortaklıklar oluşturabilmektedirler. Dolayısıyla bu durum, ülkeler için lojistik ve inovasyon boyutlarının birbirlerini tamamladığını ve inovasyon ile lojistik boyutlarının ülkeler için sinerji özelliği kazanabileceğini göstermektedir.

Ülkeler lojistik uygulamalarını inovatif faaliyetler ile anlam kazandırmalarından ve inovatif faaliyetlerle lojistik uygulamalarını çeşitlendirmelerinden ve farklılaştırmalarından dolayı uluslararası pazarda ya da piyasada lojistik alanında tutulabileceklerdir. Ayrıca ülkeler, lojistik faaliyetlerini anlamlı olarak yoğunlaştıklarında, lojistik konularında uzmanlaşabilecekler, lojistik inovasyonun gelişmesine ivme kazandırabilecekler ve genel anlamda inovasyon faaliyetlerinin yöntemlerini daha verimli olarak geliştirebileceklerdir. Dolayısıyla ülkeler, inovasyon ve lojistik boyutlarını birbirleri ile ilişkilendirebilecek ve tamamlayabilecek faaliyetler sağlamasıyla inovasyon ve lojistik boyutlarının küresel anlamda gelişimini hızlandırabilecekler ve rekabet üstünlüğü sağlayabileceklerdir. Buna bağlı olarak ülkeler, ekonomilerinin büyümelerini, gelişmelerini ve kalkınmalarını sağlayabilerek yaşam kalitelerini, yaşam standartlarını, refah düzeylerini ve istihdam oranlarını artırabileceklerdir.

Uluslararası alanda ülkelerin inovasyon ve lojistik performanslarını ölçen bazı ölçütler ve endeksler bulunmaktadır. Ülkelerin inovasyon alanında performanslarının tespit edilmesine yönelik uluslararası ortamda en çok dikkate alınan ölçütlerden biri küresel inovasyon endeksi, lojistik alanında ise lojistik performans endeksidir. Söz konusu bu endeksler ile ülkelerin inovasyon ve lojistik performansları karşılaştırılabilmektedir. Bu çalışmada kavramsal çerçeve kapsamında inovasyon, küresel inovasyon endeksi, lojistik, lojistik performans endeksi, inovasyon ve lojistik boyutları arasındaki ilişki yapısı ile ilgili açıklamalarda bulunulmuştur. Çalışmanın literatür kısmında ise inovasyon ve lojistik boyutları arasındaki ilişkileri açıklayan araştırmalar ve çalışmalar belirtilmiştir. Çalışmanın devamında, G7 ülkelerinin (Almanya, A.B.D, Birleşik Krallık, Fransa, İtalya, Japonya ve Kanada) küresel inovasyon ve lojistik performans bileşenlerine ait değerler üzerinden inovasyon ve lojistik boyutları arasındaki ilişkiler çok boyutlu olarak değerlendirilmiş ve çıkarımlar elde edilmiştir.

\section{Kavramsal Çerçeve}

Inovasyon kelimesi köken olarak latince "inovatus" kelimesinden türetilmiştir. İnovatus kelimesi ise yenilemek, yenilenmek ve yeni kavramlarının bileşiminden oluşturulmuştur (Giunchiglia, 2013). İnovasyon kavramı genel anlamda bir olayla ve durumla ilgili olarak daha önce var olmayan fikirlerin ortaya atılmasını ve pratikleştirilmesini kapsayan bir süreci belirtmektedir. Bunun yanında inovasyon kavramının sonucunu fikirlerin pratikleşmesiyle meydana gelen çeşitlenme ve farklılaşma oluşturmaktadır (Yalçınkaya, 2010: 384).

Inovasyonun temelini yenilik oluşturmaktadır. Yenilik, işletmeler açısından organizasyonların uygulamalarında ve iş yeri örgütlenmelerinde dış ilişkilerinde kıymetlendirilen ve iyileştirilen ürünün çıktı olarak meydana gelme sürecini ve pazarlama konusunda organizasyonel metotların sağlanmasını açıklamaktadır. Bunun yanında inovasyonun teorik olarak anlam kazanması için yenilik uygulamalarının ve faaliyetlerin sağlanması gerekmektedir. Bu kapsamda yenilik faaliyetleri, yeniliklerin sağlanmasında 
faydalanılan bilimsel, teknik, organizasyonel, finansal ve ticari adımları kapsamaktadır (OECD ve Eurostat, 2005: 50-51).

Schumpeter inovasyon kavramını "kalkınmanın ve gelişmenin itici gücü" olarak açıklamaktadır. Shumpeter inovasyon kavramının temelini genel olarak ekonomik yapılar üzerine dayandırmıştır. Shumpeter bu kapsamda inovasyonu teknolojinin, pazarın ve organizasyonel amaçların bileşimi olarak belirtmektedir (Hagedoorn, 1996: 887). Schumpeter (1934), ayrıca mevcut kaynakların farklılaşması ve çeşitlenmesi ile daha öncekinden farklı olarak sunulmasının inovasyonun temel yapısını oluşturduğunu düşünmektedir.

Schumpeter (1934), ekonominin gelişimini ve değişimini tetikleyen inovasyonun beş temel çeşidinin olduğunu belirtmektedir. Bunlar; yeni bir ürünün veya yeni bilinen türün piyasaya sürülmesi, bir ürünün yeni üretim veya satış yöntemlerinin uygulanması, yeni pazarın açılması, yeni hammadde veya yarı mamul tedarik kaynakların alımı ve organizasyonel inovasyon faaliyetleri aracılığıyla bir organizasyonda faaliyet yapma yöntemlerindeki değişimlerin sağlanarak yeni endüstriyel organizasyonların oluşturulması olarak tasniflenmiştir. Oslo klavuzunda ise inovasyon çeşitleri Schumpeter'in inovasyon düşüncesini temel alarak dört boyutta kategorize edilmiştir. Söz konusu Oslo klavuzuna göre inovasyon çeşitleri ve onların açıklamaları aşağıda belirtilmiştir (OECD ve Eurostat, 2005: 52-55).

1. Ürün ve Hizmet Yeniliği: Bir ürünün veya hizmetin önceki durumuna göre daha iyi olduğunu belirtmektedir. Ürün ve hizmet yeniliğinde, ürünün ve hizmetin bileşenlerinde, malzemelerinde, bütünleşmiş yazılımlarında iyileşmeyi ve üründen ve hizmetten faydalananların kolaylık sağlamasını amaçlanmaktadır.

2. Süreç Yeniliği: Yeni veya çok iyi derecede geliştirilmiş olan üretimin veya sevkiyat metotlarının sağlanmasıdır. Söz konusu bu yenilikler tekniklerdeki, teçhisatlardaki ve yazılımlardaki gelişimleri ve değişimleri içermektedir. Süreç yeniliğinde, üretim ve sevkiyat maliyetlerini düşürmek, kaliteyi yükseltmek veya sağlamlaştırılan ürünleri üreterek onları ilgililere ulaştırmak amaçlanmaktadır.

3. Pazarlama Yeniliği: Ürünün tasarımındaki, ambalajlanmasındaki, konumlandırımasındaki, tanıtımındaki ve fiyatlandırımasındaki değişimleri ve gelişmeleri sağlayan pazarlama metodudur. Pazarlama yeniliğinde, müşterilerin gereksinimlerini karşılamak, yeni pazarlar oluşturmak ve ürünün öncesinden farklı olarak konumlandırmak amaçlanmaktadır.

4. Organizasyonel Yenilik: Organizasyonların ticaret konularındaki faaliyetlerinin, iş yeri yapılarının ya da dış ilişkilerinde farklı ve yeni organizasyonel metotların uygulanmasıdır. Organizasyonel yeniliklerde yönetsel ve işlem maliyetleri azaltmak, çalışanların memnuniyetlerini artırmak, ticari olmayan varlıklara ulaşım sağlamak, araç ve gereç maliyetlerini düşürmek ile organizasyon performansı artırmak amaçlanmaktadır.

İnovasyonun etki alanının geniş olmasından dolayı inovasyon bilim, teknoloji, teknik, spor, sağılık, sanat, ekonomi, ticaret, sosyal vb. gibi alanlarda değişmeleri ve gelişmeleri sağlayabilmektedir. Dolayısıyla ülkeler, inovasyon uygulamalarını fayda sağlayacak temel faaliyetler olarak nitelendirmektedirler (Asdonk, Bredeweg ve Kowol, 1991).

İnovasyon ülkelerin ekonomilerinin büyümesinde, gelişmesinde ve kalkınmasında önemli bir rol oynamakta olup, ülkelere ekonomik yönden fayda sağlamasında ve olumlu getirilerin elde edilmesinde katalizör görevi üstlenmektedir. Buna bağlı olarak ülkeler, ayrıca inovasyon sayesinde dolaylı olarak yaşam kalitelerini, yaşam standartlarını ve refah düzeylerini artırabilmektedirler. Inovasyon ile ülkeler temel anlamda her alanda çeşitlenme ve farklılaşma oluşturabilmektedirler. Söz konusu bu çeşitlenmeler ve farklılaşmalar ülkeler, toplumlar ve organizasyonlar için kolaylık sağlayıp onların gereksinimlerini karşılayabilmekte ve buna bağlı olarak ülkeler küresel pazarda tutunmayı sağlayabilmektedirler. Bunun yanında ülkeler, inovasyon ile oluşan çeşitliliklerin ve farklılaşmaların sürdürülebilirliğini sağladığı sürece rekabet üstünlüğünün de sürdürülebilirliğini oluşturabilmektedirler (Porter ve Van der Linde, 1995).

Ülkelerin kendi inovasyon performansları hakkında bilgi sahibi olmaları çok önemlidir. Çünkü ülkeler bu sayede inovasyon uygulamaları hakkında üstünlüklerini, potansiyellerini, kapasitelerini, yeteneklerini ve 
eksikliklerini tespit edebileceklerdir. Dolayısıyla ülkeler, kendi inovasyon performanslarının farkındalığı ile inovasyon konusundaki eksikliklerini telafi etmek veya geliştirilmesi gereken hususlarda iyileşme sağlamak için sonraki dönemlerdeki inovasyon süreçlerinin yöntemlerini, yönetimlerini, stratejilerini ve uygulamalarını daha nitelikli yapabileceklerdir.

Ülkeler birbirlerinin inovasyon performanslarını da bilmelerine gereksinim duymaktadırlar. Çünkü ülkeler, inovasyon konusundaki yetersizliklerinin yeterli hale getirmeleri ve inovasyon konusunda geliştirilmesi gereken hususlarda daha iyi performans sağlamaları maksadıyla inovasyon performansı yüksek olan ülkeler ile işbirlikleri ve ortaklıklar sağlayabilmektedirler. Böylelikle ülkeler, inovasyon konusunda birbirlerini tamamlayıcı bir yapı sergileyebilmektedirler. Dolayısıyla bu durum, inovasyon boyutunun sinerji özelliğini kazanmasına neden olabilmektedir. Çünkü inovasyonun spesifik ve farklı konularında performans gösteren ülkeler, birbirleriyle olan ilişkiler ve işbirlikleri ile küresel inovasyonun gelişmesine ve buna bağı olarak inovasyonun etkilediği tüm disiplinlerde ve alanlarda gelişim sağlanmasına neden olabilmektedirler. Sonuç olarak ülkeler, kendilerinin ve birbirlerinin inovasyon performanslarını ölçecek metriklere veya endekslere her zaman ihtiyaç duymaktadırlar.

Ülkelerin inovasyon performansları küresel inovasyon endeksi kapsamında ilk olarak 2007 yılında INSEAD isimli işletme alanında yükseköğrenim veren bir kurum tarafından ölçülmüştür (INSEAD, 2007). Sonrasında ise küresel inovasyon endeksi ile ülkelerin küresel inovasyon performanslarının ölçüm çalışmasına 2011 yılında Dünya Fikri Mülkiyetler Örgütü (WIPO) (INSEAD ve WIPO, 2011), 2013 yılında ise Cornell Üniversitesi katılmıştır (Cornell University, INSEAD ve WIPO, 2019).

Küresel inovasyon endeksi, inovasyon girdi ve inovasyon çıktı alt dizi olmak üzere iki dizinden oluşmaktadır. Inovasyon girdi alt dizinini "kurumlar", "beşeri sermaye ve araştırma", "altyapı", "pazar gelişmişliği", "iş gelişmişliği" bileşenleri, inovasyon çıktı alt dizinini ise "bilgi ve teknoloji çıktısı" ve "yaratıcı çıktısı" bileşenleri oluşturmaktadır (Hancıoğlu, 2016: 139; Jankowska, Matysek, Jedrych ve Mroczek, 2017: 181). Bu kapsamda küresel inovasyon endeksini oluşturan dizinler, dizinlere ait bileşenler ve bileşenlere ait değişkenler Tablo 1'de sunulmuştur.

Tablo 1. Küresel İnovasyon Endeksi Dizinleri, Bileşenleri ve Değişkenleri

\begin{tabular}{|c|c|c|c|c|}
\hline \multicolumn{5}{|c|}{ KÜRESEL INOVASYON ENDEKSI } \\
\hline \multicolumn{5}{|c|}{ iNOVASYON GIRDI ALT DIZINI } \\
\hline BiLEŞENLER & \multicolumn{4}{|c|}{ BİLEŞENLERE BAĞLI DEĞiŞKENLER } \\
\hline Kurumlar & Beşeri Sermaye ve Araştırma & Altyapı & $\begin{array}{c}\text { Pazar } \\
\text { Geliş̧mişliği }\end{array}$ & İş Gelişmişliği \\
\hline Politik Ortam & Eğitim & $\begin{array}{l}\text { Bilgi ve İletişim } \\
\text { Teknolojileri }\end{array}$ & Kredi & Kalifiye İşçi \\
\hline Düzenleyici Ortam & Yüksek Öğretim & Genel Altyapı & Yatırım & $\begin{array}{c}\text { Yenilik } \\
\text { Bağlantıları }\end{array}$ \\
\hline İş Ortamı & $A E-G E$ & $\begin{array}{c}\text { Ekonomik } \\
\text { Sürdürülebilirlik }\end{array}$ & $\begin{array}{l}\text { Ticaret ve } \\
\text { Rekabet }\end{array}$ & Bilgi Emilimi \\
\hline \multicolumn{5}{|c|}{ INOVASYON ÇIKTI ALT DIZINI } \\
\hline Bileşenler & \multicolumn{4}{|c|}{ BiLEŞENLERE BAĞLI DEĞiŞKENLER } \\
\hline Bilgi ve Teknoloji Çıktısı & Bilgi Yaratma & Bilgi Etkisi & \multicolumn{2}{|c|}{ Bilgi Yayılması } \\
\hline Yaratıcı Çıktısı & Maddi Olmayan Varlıklar & $\begin{array}{c}\text { Yaratıcı Mal ve } \\
\text { Hizmetler }\end{array}$ & \multicolumn{2}{|c|}{ İnternet Üzerinden Yaratıcılık } \\
\hline
\end{tabular}

Kaynak: Ay Türkmen ve Aynaoğlu, 2017: 262'den uyarlanmıştır. 
Tablo 1'de inovasyon bileşenlerini açıklayan değişkenler bulunmaktadır. Söz konusu bileşenlerin ve bileşenleri oluşturan değişkenlerin birbirlerini tamamlayıcı özelliklerinin olması, inovasyon bileşenlerinin ve değişkenlerinin ortak özelliğini göstermektedir. Ayrıca Tablo 1'de belirtilen küresel inovasyon endeksini oluşturan inovasyon girdi ve çıktı alt dizinleri, dizinlere bağlı bileşenler ve bileşenlere bağlı alt değişkenler haricinde her bir değişkene bağlı alt değişkenlerde bulunmaktadır. Bütünsel olarak küresel inovasyon endeksi, 2 alt dizinden, 2 alt dizine bağlı 7 bileşenden, 7 bileşene bağlı 21 değişken ile 21 değişkene bağlı 103 alt değişkenden oluşmaktadır (Cornell University vd., 2019).

Lojistik kavramının kökeni Fransızca'dan gelmekte olup, "logistique" kelimesinden türetilmiştir. Lojistik kavramı, barış ve sefer koşullarında orduların personel, teçhisat, malzeme, mühimmat vb. çeşitli gereksinimlerin sağlanması anlamında kullanılmıştır. Yönetim teorisinde ve bilgi sistemindeki çeşitli gelişmeler doğrultusunda organizasyonlar ve büyük organizasyonlar olarak nitelendirilen ülkeler için lojistik kavramının önemi artmıştır. Özellikle 1970'li yıllardan sonra ise lojistik kavramı, üretim sektörünün anlam kazanması için alanında uzmanlaşılması gereken bir disiplin olarak nitelendirilmiştir (Bayraktutan, Tüylüoğlu ve Özbilgin, 2012: 62; Lambert ve Cook, 1990).

Lojistik faaliyetleri sevkiyat, depolama, paketleme, katma değerli hizmetler, gümrük, sipariş yönetimi, stok yönetimi, sigorta, muayene ve gözetim olarak belirtilmektedir. Bunlardan nakliyat ve depolama ana ve ürün akışı lojistik fonksiyonlarının, paketleme ve katma değerleri işlemleri tamamlayıcı ve ürün akışı fonksiyonlarının, gümrükler, sipariş yönetimi, stok yönetimi, sigorta, muayene ve gözetim ise tamamlayıcı ve hizmet akışı fonksiyonlarının değişkenleri olarak belirtilmektedir (Pfohl, 2008: 7-8).

Lojistik boyutunun doğru lojistik faaliyetlerin gerçekleştirilmesi ya da lojistik hedeflerin doğru tespit edilmesi kapsamında 7 adet etkinlik amacı bulunmaktadır. Bu etkinlik amaçları "doğru ürünü, doğru yer, doğru zaman, doğru miktar, doğru şekil ve doğru maliyet" ile "planlanan hızla" müşterilere sunma olarak belirtilmiştir (Horenshteyn, 2009: 3).

Ülkeler ve organizasyonlar için özellikle küreselleşmenin bir sonucu olarak değişme ivmesi fazla olan rekabet şartlarının varlığı, ekonomik ve ticari faaliyetlerin küresel ortamda hız kazanması ve inovasyon faaliyetlerine (farklılaşma ve çeşitlenme) olan ihtiyaç çerçevesinde ürünlerin yaşam zamanlarının azalabilmesi, kar marjlarının düşebilmesi, farklılaşan ve çeşitlenen teknoloji gereksinimlerin ortaya çıkması, tüketici memnuniyetlerinin en seviyeye çıkarılması koşulları sebebiyle lojistiğin önemi artmış olup, lojistik konusunun alanında çalışılması ve lojistiğin ilgilendiği konuların değişen koşullar çerçevesinde geliştirilmesi intiyacı duyulmuştur (Erdoğan, 2019: 93). Çünkü ülkeler ve organizasyonlar, lojistik anlamda uluslararası alanda çevre içinde iç etkiler (güç ilişkileri), dış etkiler (mevzuat ve piyasa etkinliği sağlama ihtiyacı), süreç sorunları (lojistik uygulama yöntemleri ve lojistik inovasyon oluşturma ihtiyacı) ve dönüşüm sorunları (lojistik konularında desteklenme gereksinimi, lojistik yeniliklerin oluşturacağı riski azaltma) şartları ile karşı karşıyadırlar (Abu Bakar, Jaafar, Faisol ve Muhammad, 2014).

Üretim aşamasından tüketim aşamasına kadar lojistik konusunda her türlü bilgi akışının etkin, etkili ve verimli şekilde oluşturulması faaliyetlerinin ekonomi ile doğrudan ilişkileri bulunmaktadır. Bu bakımdan lojistik faaliyetleri, özellikle ülkelerin ekonomik ve ticari üstünlük ile rekabet gücünün sağlanması için önemli bir araç haline gelmiştir. Ayrıca lojistik hizmetlerin etkin, etkili ve verimli olarak yürütülmesi ile ülkeler ve kıtalar arası ticaret hacmi yükselebilecek, yatırımlar artabilecek ve bunlara bağlı olarak ülke ekonomilerinin büyümeleri, gelişmeleri ve kalkınmaları sağlanabilecektir (Hammer, 2009; Gökkısa ve Ayçin, 2019: 302; Yangınlar, 2019: 69; Ateş ve Işık, 2019;).

Ülkelerin kendi lojistik performanslarını takip etmeleri sonucunda ülkeler lojistik konularında sonraki süreçlerde önem verilmesi ve geliştirilmesi gereken hususlar için çeşitli çalışmalar yapabilmektedirler. Böylelikle ülkeler, lojistik faaliyetlerini plan veya planlar dahilinde oluşturarak uygun lojistik stratejilerini tespit edebilirler. Ayrıca ülkeler, birbirlerinin lojistik performanslarını takip etmektedirler. Çünkü ülkeler, lojistik konularındaki eksikliklerini ve geliştirilmesi gereken hususlar konusunda lojistik performansı iyi olan ülkeler ile lojistik konularında işbirlikleri ve ortaklıklar sağlayabilmektedirler. Böylelikle ülkeler, lojistik konularında birbirlerini tamamlayarak küresel anlamda lojistiğin, ekonominin, ticaretin ve inovasyon 
faaliyetlerinin genel anlamda gelişimlerine katkıda bulunabilmektedirler. Aynı zamanda lojistik performanslarını geliştiren ülkeler, diğer ülkelere için yatırımların gerçekleşmesine aracı olabilmektedirler.

Lojistik faaliyetlerin ülkeler açısından önemi, ülkelerin kendilerinin ve birbirlerinin lojistik potansiyelleri, yeterlilikleri ve üstünlükleri hakkından bilgi sahibi olmalarına olan ihtiyaçları kapsamında, ülkelerin lojistik kapasitelerini geliştirmeleri ve lojistik konularında eksiklerini gidermeleri ve bunlara bağı olarak daha verimli lojistik faaliyetleri gerçekleştirmek için ülkelerin lojistik performanslarını ölçen metriklere veya endekslere ihtiyaç duyulmuştur (Mentzer ve Firman, 1994; Ulutaş ve Karaköy, 2019).

Ülkelerin lojistik performanslarının ölçülmesinde uluslararası alanda en çok dikkate alınan ölçütlerden bir tanesi Dünya Bankası tarafından oluşturulan lojistik performans endeksidir. Bu endeks ile ülkelerin lojistik performanslarının ölçümü ilk olarak 2007 yılında gerçekleştirilmiştir (Forte, D’ambra ve Siviero, 2012: 8).

Lojistik performans endeksinde ülkelerin lojistik performansları 5 kategoride tasniflenmiştir. Birinci kategoride yer alan ülkeler "lojistik dostu", ikinci kategoride yer alan ülkeler "istikrarlı performansa sahip olanlar", üçüncü ve dördüncü kategoride yer alan ülkeler "kısmi performansa sahip olanlar" ve beşinci kategoride yer alanlar ülkeler ise "lojistik dostu olmayan ülkeler" olarak açıklanmışlardır (Arvis vd., 2018). Ayrıca lojistik performans değerleri 1 ile 5 değerleri arasındadır. 1 en az, 5 ise en fazla performans değerini göstermektedir. 1 ile 5 arasındaki değerler ise Likert skalası olarak değerlendirilmektedir (Akdoğan, 2017: 625).

Lojistik performans endeksi 6 bileşenden oluşmaktadır. Söz konusu bileşenlerin birbirleri ile pozitif yönlü ilişkileri bulunmaktadır. Bu anlamda lojistik performans endeksi bileşenleri ve bileşenlerin açıklamaları aşağıda belirtilmiştir (Yapraklı ve Ünalan, 2017: 594; Arvis vd., 2018).

1. Gümrük: Gümrük işlemlerinin ve süreçlerinin verimliliğini açıklar.

2. Altyapı: Ticaret ve taşımacılık arasındaki ilişki altyapısının kalitesini açıklar

3. Uluslararası Nakliyat: Uluslararası sevkiyatların düzenlenmesindeki kolaylıklar ve maliyetlere katlanma düzeylerini açıklar.

4. Lojistik Kalitesi ve Yetkinlik: Yerel lojistik sektörünün kalitesini ve yetkinliğini açıklar.

5. Zamanlama: Nakliyatların varış yerlerine planlanan zamanında gelme durumunu açıklar.

6. Takip ve İzleme: Uluslararası sevkiyatları izleyebilme yeteneğini açıklar.

Lojistik performansı bileşenleri arasındaki ilişkiler neticesinde, lojistik performansı bileşenlerin girdiler ve çıktılar olarak kategorize edilmesine göre model oluşturulmuştur. Söz konusu bu model Tablo 2'de gösterilmiştir.

Tablo 2. Lojistik Performans Girdi ve Çıktı Bileşenleri

\begin{tabular}{|c|c|c|}
\hline GIRDiLER & $\begin{array}{c}\text { MODERATÖR } \\
\text { DEĞiŞKEN }\end{array}$ & ÇIKTILAR \\
\hline POLiTiKA DÜZENLEMELERi içiN ALANLAR & \multirow{5}{*}{ 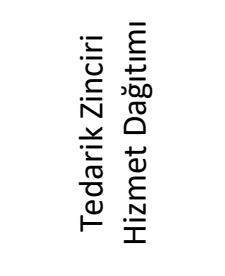 } & HIZMET DAĞITIM PERFORMANSI \\
\hline BILEŞENLER & & BILEŞENLER \\
\hline Gümrükler & & Zamanlama \\
\hline Altyapı & & Uluslararası Sevkiyatlar \\
\hline Lojistik Kalite ve Yetkinlik & & Takip ve İzleme \\
\hline
\end{tabular}

Kaynak: Arvis vd., 2018'den uyarlanmıştır. 
Tablo 2'ye göre gümrükler, altyapı ile lojistik kalitesi ve yetkinlik bileşenleri girdileri (politika düzenlemeleri için alanlar), zamanlama, uluslararası sevkiyatlar, takip ve izleme bileşenleri ise çıktıları (hizmet dağıtım performansı) oluşturmaktadır. Söz konusu girdilere ve çıktılara ait genel değerler lojistik girdilerine ve çıktılarına bağlı olan lojistik bileşenlerinin aritmetik ortalamaları ile hesaplanmaktadırlar (Duran ve Türkoğlu, 2019: 89).

İnovasyon ve lojistik kavramları birbirleri ile pozitif yönde karşııklı ilişki içinde olup, birbirlerini tamamlamaktadırlar. Bu kapsamda inovasyon boyutunun lojistik boyutunu etkilemesiyle, lojistik alanında farklılaşma ve çeşitlenme sağlanarak ülkelerin lojistik performansları artabilecektir. Lojistik faaliyetlerinin belirli yöntemler, stratejiler, planlar ve uygulamalar dahilinde etkinliklerinin olmasıyla ülkeler lojistik konularında sürekli öğrenmelerini, yoğunlaşabilmelerini ve uzmanlaşabilmelerini sağlayarak lojistik alanında inovatif faaliyetlerini oluşturabilmektedirler.

Lojistik faaliyetlerinde farklılaşma ve çeşitlenme lojistik performansın oluşmasında önemli bir rol oynamaktadır. Dolayısıyla lojistik alanında farklılaşmaların ve çeşitlenmelerin oluşması için lojistik faaliyetlerinde inovasyon faaliyetlerinin oluşturulması gerekmektedir (Fugate, Mentzer ve Stark, 2010: 45; Elbert ve Özsucu, 2012: 54). Bunun yanında inovasyon ile beslenen lojistik faaliyetler sayesinde ülkeler rekabet üstünlüğünü veya rekabet ortamına katlanma durumlarının artmalarını sağlayabilmektedirler. Dolayısıyla lojistik faaliyetlerinde farkıılaşma ve çeşitlenme, ülkeler açısından rekabet ortamında üstünlüğün sağlanması açısından önemli bir fırsat olarak görülebilmektedir. Çünkü ülkelerin lojistik faaliyetleri, inovasyon ile katma değeri ve olumlu getiriyi sağlayabileceğinden dolayı ülkeler uluslararası pazarda veya piyasada (çevrede) tutunabileceklerdir. Bu durum, doğal olarak ülkelerin inovasyon faaliyetlerini sürdürülebilirliğini sağlamalarına bağlı olmaktadır. Çünkü ülkelerin lojistik konusundaki farklılaşmaları ve çeşitlenmeleri, ülkelerin uluslararası pazarda lojistik açıdan stratejik bir kaynak olarak değerlendirilmelerine neden olabilmektedir. Dolayısıyla inovasyon ile beslenen veya desteklenen lojistik faaliyetleri sayesinde ülkeler lojistik anlamda organizasyonların veya diğer ülkelerin gereksinimlerini hızlı ve zamanında karşılayarak uygun tedarik programları uygulayabileceklerdir (Boscacci, 2003; Burmaoğlu, 2012: 195-197; Kazançoğlu ve Şeşen, 2015: 41-42; Bekmezci ve Aksungur, 2018; Burmaoğlu, Erdal ve Korucuk, 2018; Lucio, 2018;).

İnovasyon faaliyetleriyle lojistik konularında müşteri ihtiyaçlarının doğru belirlenmesi ile lojistik yeniliklerin maliyetlerinin ve faydaların doğru değerlendirilmesine ve verimli lojistik yönetimlerinin daha sağlıklı olarak işleyebilmesine neden olabilecektir (Kernsten, Herstatt, von See ve Kalogerakis 2016: 4-5). Dolayısıyla bu durum, müşterilerin sipariş zamanları ile teslim zamanı arasındaki süreyi azaltabilecek (Griese ve Sieber, 2000: 308), müşteri sadakatini ve memnuniyetini artırabilecek ve müşterilerin beklentilerini karşılayabilecektir (Witkowski, 2017: 765; Bekmezci ve Aksungur, 2018; Erenel ve Kaya, 2018: 408).

İnovasyon çeşitlerinden olan süreç yeniliklerinin amaçlarından bir tanesi lojistik maliyetlerini azaltmak ve iyileştirilmiş sevkiyat metotlarını oluşturmaktır. Dolayısıyla lojistik performansın süreç yenilikleri ile doğrudan ilişkisi bulunmaktadır. Bu anlamda lojistik alanında inovasyon döngüsünün sağlanması için lojistik odaklı çözümlere gereksinim duyulmaktadır (Olavarrieta ve Ellinger, 1997: 559). Bu durum inovasyon faaliyetlerin lojistik faaliyetlerinden de beslenebileceğini göstermektedir. Çünkü lojistik faaliyetlerindeki uzmanlaşma, yoğunlaşma ve lojistik konularında spesifikleşme, lojistik konularında yeni inovasyon faaliyetlerin oluşmasını sağlamaktadır. Ülkelerin lojistik faaliyetlerinin çoğalması ve lojistik sektöründe deneyim kazanmaları, ülkelerin lojistik konusunda sürekli öğrenmelerini ve öğrenme ivmelerinin artırmalarına neden olabilecektir. Böylelikle ülkeler, rekabet koşulları içinde uluslararası pazarda veya piyasada tutulabileceklerdir.

\section{Literatür}

İnovasyon ve lojistik boyutlarına ilişkin literatürde yapılmış çalışmalar olmakla birlikte, küresel inovasyon endeksi ile lojistik performans endeksi arasındaki ilişkiyi belirlemeyi amaçlayan çalışmaların literatür araştırmasında çok az olduğu tespit edilmiştir. Bununla birlikte, literatürde inovasyon ve lojistik boyutları arasındaki ilişkiyi ölçmeyi amaçlayan çalışmalar çoğunlukla ülkeler bazında değil, organizasyonlar düzeyindedirler. 
Sauvage (2003), Fransız lojistik firmaları üzerinden yaptığı araştırmaya göre, rekabetçi bir ortamda bulunan Fransız lojistik firmaların farklılaşmalara, çeşitlenmelere, dış kaynak elde etme başarıların sağlamalarına ve tedarik zinciri faaliyetlerinin iyileştirilmesine gereksinim duyulduğu ve buna bağlı olarak inovasyon kapsamında Fransız lojistik firmaların yeni beceriler ve yenilik faaliyetlerini elde etmeleri gerektiğini belirtmektedir. Richey, Genchev ve Daugherty (2005), otomobil firmaları üzerindeki araştırmasında ters lojistik, kaynak taahhüdü ve inovasyon arasındaki ilişkileri incelemişlerdir. Araştırma sonucuna göre, kaynak taahhüdünün lojistik programlarını ve faaliyetlerini sağlayamadığı, buna karşın inovasyon faaliyetlerinin lojistik faaliyetlerinin etkin, etkili ve verimli olmasını sağladığı tespit edilmiştir. Chieh ve Yi (2007), Çin Halk Cumhuriyeti ülkesindeki lojistik firmaların inovasyon faaliyetlerinin lojistik boyutu kapsamında tedarik zinciri performansları üzerindeki etkiyi araştırmışlardır. Araştırmada lojistik firmaların inovasyon kapsamında teknolojik yeniliklerini benimsemelerinin lojistik firmaların tedarik zinciri performanslarını artırdığı açıklanmıştır. Phohl, Kohler ve Röth (2008), küresel anlamda tedarik zincirinin ülkelere göre farklı yöntemlerle ve araçlarla desteklendiğini ve ayrıca yenilikçi tedarik zinciri uygulamalarının finansal ve yasal yönlerinin lojistik faaliyetlerin verimliliği için daha fazla dikkate alınması gerektiğini belirtmişlerdir. Ho, Lin ve Chiang (2009), Tayvan ülkesindeki lojistik firmaları üzerinden yaptığı araştırmada lojistik şirketlerinin lojistik boyutu kapsamında uygulamış oldukları organizasyon desteklerinin, beşeri sermaye kalitesinin ve organizasyon bilgi birikimlerinin söz konusu lojistik firmaların inovasyon faaliyetlerine olumlu ve verimli olarak etkilediğini ifade etmişlerdir. Fugate vd. (2010), Dünya Tedarik Zinciri Yönetim Konseyi'ne üye firmalar üzerinden lojistik etkinliğin, etkililiğin ve farklılaşmanın (inovasyon) lojistik performansı ve lojistik performansının organizasyonel performansı nasıl etkilediğini araştırmışlardır. Araştırma sonucuna göre, lojistik etkinliğin, etkililiğin ve farklılaşmanın (inovasyon) lojistik performansı ve lojistik performansın organizasyonel performansı anlamlı ve pozitif yönlü etkilediği tespit edilmiştir. Özellikle lojistik alanında inovasyon faaliyetlerin sonucunu oluşturan lojistik farklılaşmanın lojistik performansı lojistik etkinlik ve etkililik değerlerine göre daha fazla ve orta seviyede etkilediği tespit edilmiştir. Daugherty, Chen ve Ferrin (2011), Çin Halk Cumhuriyeti ülkesinde elektrik endüstrisi firmaları üzerinden söz konusu firmalardaki inovasyon faaliyetlerinin firmaların lojistik performanslarına olan etkisini araştırmışlardır. Araştırmacılar, inovasyon kapsamında firmaların yerel yönetim ve formalleştirme uygulamalarının firmaların lojistik hizmet inovasyon yeteneklerinin olumlu şekilde etkilediği bulgusuna ulaşmışlardır. Karsten, Seidel ve Stolze (2012), lojistik firmaların lojistik konusunda oluşturacakları yenilik faaliyetleri ile rekabet üstünlerini sağlayabileceklerini açıklamışlardır. Ayrıca Lampe ve Stolz (2012), lojistik firmaların tedarik zinciri yönetiminde ve lojistik faaliyetleri kapsamındaki inovatif tasarımları, lojistik firmaların lojistik performanslarını artırabileceğini tespit etmişlerdir. Hassan, Shaukat, Nawaz ve Naz (2013), Pakistan ülkesinde stok yönetiminde faaliyet gösteren lojistik firmaları üzerinden ürün inovasyonu, süreç inovasyonu, pazar inovasyonu ve organizasyonel inovasyon arasındaki ilişkileri araştırmışlardır. Çalışmada ölçüm araçlarından lojistik konularının daha çok süreç inovasyonu ilgilendirdiği tespit edilmiştir. Araştırma sonucuna göre, süreç inovasyonunun (lojistik inovasyon) diğer inovasyon türleri ile anlamlı, pozitif yönde ve orta düzeyde ilişkileri olduğu tespit edilmiştir. Şipoş ve Bizoi (2015), 24 Avrupa ülkesinin 2012 yılı için özet inovasyon endeksi (Summary Innovation Index) ve lojistik performans endeksini oluşturan bileşenlere ait değerler üzerinden inovasyon boyutunun lojistik boyutuna olan etkisini incelemişlerdir. Bulgulara göre, inovasyon boyutu lojistik boyutunu anlamlı, pozitif yönde ve yüksek düzeye yakın olarak etkilediği tespit edilmiştir. Witkowski (2017), Avrupa ülkelerinin, A.B.D’nin ve Çin'in internet uygulamaların (nesnelerin interneti), büyük verilerin ve Endüstri 4.0 inovasyon faaliyetlerinin lojistik ve tedarik zincirine olan etkilerini araştırmıştır. Bulgulara göre, belirtilen inovasyon faaliyetlerinin lojistik performansı sağlamasının yüksek seviyede olduğu açıklanmıştır.

Burmaoğlu (2012), Avrupa Birliği ülkelerinin lojistik performans endeks ve Avrupa Birliği izolasyon karnelerinde yer alan inovasyon bileşenlerine ait değerler üzerinden inovasyon ile lojistik performansları arasındaki ilişkiyi araştırmıştır. Bulgulara göre, lojistik ve inovasyon performanslarını belirleyen bileşenler arasında pozitif yönlü ve anlamlı ilişkilerin olduğu bulgusuna ulaşılmıştır. Erkan (2014), 2014 yılı için 133 ülke üzerinden lojistik performans endeksi bileşenleri ile küresel rekabet endeksi bileşenleri arasındaki ilişkileri araştırmıştır. Araştırmada, inovasyon değişkeninin küresel rekabet endeksinin bir bileşeni olması kapsamında, söz konusu ülkelerin verilerine istinaden inovasyon bileşeninin lojistik performansa etkisinin pozitif yönlü ve anlamlı olduğu tespit edilmiştir. Alnıpak ve Alkan (2017), inovasyon boyutu ve sanayi 4.0 kapsamında dijitalleşme, otonomi, katma değer ve sürdürülebilirlik konularının tedarik zincirinin ve lojistik 
faaliyetlerinin en önemli bileşenlerinden biri olan limanlarda uygulanmasının öneminden bahsetmişlerdir. Araştırmacılar inovasyon faaliyetleri ile sistem entegrasyonlarının verimli olacağını ve buna bağlı olarak lojistik faaliyetlerde bölümler arası veri akışının en optimal bir şekilde sağlanabileceğini, maliyetlerin azalabileceğini ve sevkiyatların daha kontrollü olarak sağlanabileceğini belirtmişlerdir. Çubukçuoğlu ve İnanoğlu (2019), organizasyonların gerçekleştireceği lojistik performanslarının, lojistik faaliyetler kapsamında inovasyon performanslarını da oluşturabileceğini ifade etmişlerdir. Taşel, Bayarçelik ve Apak (2019), lojistik faktöründeki faaliyetler kapsamında lojistik firmaların büyüklüğünün, yönetim yeteneklerinin ve gelişme kapasitelerinin inovasyon faktöründe en önemli değişkenler olduğunu açıklamışlardır. Bilgiç, Türkmenoğlu ve Koçak (2020), inovasyon faaliyetleri ile lojistik kapsamında dijital yeniliğin, veri odaklı çevikliğin, dijital ortam yönetiminin, bilim teknolojilerinin değişiminin ve otomasyonun sağlanabileceğini belirtmişlerdir. Dolayısıyla araştırmacılar, inovasyon ile sağlanabilecek yeni teknolojiler ve dijital sistemlerle lojistik faaliyetlerin verimli olabileceğini değerlendirmişlerdir.

İnovasyon ile lojistik boyutları arasındaki ilişkileri inceleyen çalışmalarda, lojistik ve inovasyon boyutları arasındaki ilişkinin sağlandığı belirtilmektedir. Dolayısıyla literatürde, inovasyon ve lojistik boyutları arasındaki ilişki kapsamında etkisel anlamda inovasyon boyutunun lojistik boyutunu, lojistik boyutunun ise inovasyon boyutunu sağladığı tespit edilmiştir. Fakat litaratür değerlendirildiğinde, araştırmalarda lojistik boyutun inovasyon boyutuna etkisinden daha çok, inovasyon boyutunun lojistik boyutuna olan etkisi incelenmiştir. Dolayısıyla inovasyon ve lojistik boyutunun birbirlerini tamamlaması kapsamında, lojistik boyutun inovasyon boyutunu etkileyen daha çok araştırmalara gereksinim duyulduğu tespit edilmiştir. Ayrıca inovasyon ve lojistik boyutunun karşılıklı etkilerini işleyen her hangi bir araştırmaya literatürde rastlanılmamıştır. Lojistik ve inovasyon boyutlarının birbirleri arasındaki ilişkilerde hangi boyutun ilişkisel yapıya katkı sağladığı, söz konusu boyutların birbirlerine olan etki katsayıları ile ölçülebilir. Bu kapsamda, inovasyon ve lojistik boyutlarının birbirleri ile olan ilişkilerinde boyutların birbirlerini belirleyen etkileme durumlarını konu alan araştırmalar yapılması intiyacı dolduğu değerlendirilmiştir. Bunların dışında, inovasyon ve lojistik boyutları arasındaki ilişkiyi konu alan araştırmalar incelendiğinde, ülkelerin endeks olarak inovasyon ve lojistik performanslarını ölçen çalışmaların çok az olduğu sonucuna ulaşılmıştır. Ülkelerin belirli yıllar kapsamında inovasyon ve lojistik performanslarını bilmelerinin önemi doğrultusunda ülkeler için inovasyon ve lojistik faaliyetlerine ilişkin olarak ülkelerin inovasyon ve lojistik performanslarının birbirlerinin tamamlama seviyelerinin ölçülmesine yönelik araştırmaların daha fazla olması gerektiği sonucuna ulaşılmıştır.

\section{Yöntem}

\subsection{Araştırmanın Amacı, Veri Seti ve Verilerin Analizi}

Araştırmanın birinci amacı, G 7 ülkelerinin inovasyon ve lojistik bileşenlerine ait değerler kapsamında inovasyon ve lojistik boyutlar arasındaki ilişkisel yapıya yüksek düzeyde katkı sağlayan inovasyon ve lojistik bileşenlerinin ilişki durumlarını, bileşenlerin ilişkiye katkı sağlama değerlerini ve inovasyon ile lojistik girdi ve çıktı setlerinin ilişkisel yapıya katkı değerlerini tespit etmektir. Araştırmanın ikinci amacı ise bütünsel anlamda inovasyon ile lojistik boyutları arasındaki ilişki düzeyini ve ilişkiye en fazla katkı sağlayan boyutu tespit etmektir.

Ülkelerin küresel inovasyon endek değerleri ilk defa 2007 yılından başlayarak en son 2019 yılı olmak üzere (toplam 13 rapor) rapor halinde sunulmuştur. Ülkelerin lojistik performansı endeksleri ise ilk olarak 2007 yılından başlayarak 2010, 2012, 2014, 2016 ve en son 2018 (toplam 6 rapor) yılı olmak üzere yine rapor dahilinde oluşturulmuştur. Ayrıca 2007 yılındaki ülkelerin lojistik performans endekslerini belirten raporda sadece ülkelerin lojistik performans endeksini bulundurması ve buna bağlı olarak lojistik performansını belirleyen bileşenlere ait değerler olmamasından dolayı ve yıllara göre ülkelerin inovasyon ve lojistik raporlarının tutarlılık göstermesi bakımından araştırmanın veri setini 2010, 2012, 2014, 2016 ve 2018 yıllarındaki G7 grubundaki ülkelere (Almanya, A.B.D, Birleşik Krallık, Fransa, italya, Japonya ve Kanada) ait küresel inovasyon ve lojistik performans endekslerini belirleyen bileşenlere ait değerler oluşturmuştur. Araştırmanın birinci amacına yönelik Pearson, ikinci amacına yönelik ise kanonik korelasyon katsayısından yararlanılmıştır. Bu kapsamda araştırmada kullanılan veri seti ve veri setindeki bileşenlerin araştırmaya kolaylık sağlaması açısından kısaltmaları Tablo 3'de sunulmuştur. 
İnovasyon ve Lojistik Boyutları Arasındaki İlişkiye Yönelik Ampirik Bir Araştırma

Tablo 3. Küresel İnovasyon ve Lojistik Performans Bileşenleri (Veri Seti) ve Bileşenlerin Kısaltmaları

\begin{tabular}{|c|c|c|c|c|c|}
\hline $\begin{array}{l}\text { Girdiler } \\
\text { Çıktılar } \\
\text { İnovasyon }\end{array}$ & $\begin{array}{l}\text { Küresel Inovasyon } \\
\text { Bileşenleri }\end{array}$ & Kısaltmalar & $\begin{array}{l}\text { Girdiler } \\
\text { Çıktılar } \\
\text { Lojistik }\end{array}$ & $\begin{array}{l}\text { Lojistik Performans } \\
\text { Bileşenleri }\end{array}$ & Kısaltmalar \\
\hline \multirow{5}{*}{ Girdiler } & Kurumlar & GKie1 & \multirow{3}{*}{ Girdiler } & Gümrükler & GLpe1 \\
\hline & Beşeri Sermaye & GKie2 & & Altyapı & GLpe2 \\
\hline & Altyapı & GKie3 & & Lojistik Kalite ve Yetkinlik & GLpe3 \\
\hline & Pazar Gelişmişliği & GKie4 & \multirow{4}{*}{ Çıktılar } & Zamanlama & ÇLpe4 \\
\hline & İş Gelişmişliği & GKie5 & & Uluslararası Sevkiyatlar & ÇLpe5 \\
\hline \multirow{2}{*}{ Çıktılar } & Bilgi ve Teknoloji Çıktısı & ÇKie6 & & \multirow{2}{*}{ Takip ve İzleme } & \multirow{2}{*}{ ÇLpe6 } \\
\hline & Yaratıcı Çıktısı & ÇKie7 & & & \\
\hline
\end{tabular}

Inovasyon ve lojistik boyutlarının pozitif yönde birbirlerini tamamlaması, ülkelerin inovasyon ve lojistik performanslarının artmasına neden olabilecektir. Dolayısıyla bu durum, ülkelerin ekonomik gelişmişliğine ve büyüklüğünün oluşmasında olumlu katkıların oluşmasını sağlayabilecektir. G7 ülkeleri dünya ekonomisinin yarısından fazlasına hakim konumdadır. Bunun yanında söz konusu G7 ülkelerinin küresel zenginlikleri, ekonomik gelişmişlikleri ve büyüklükleri birçok ülkeden fazla değerdedirler. Ayrıca söz konusu ülkelerin ilgili raporlar kapsamında yıllara göre küresel inovasyon ve lojistik performans endeks nicelikleri yüksek değerdedirler. Bütün bunlar düşünüldüğünde, G7 ülkelerinin inovasyon ve lojistik konusundaki girişimleri, stratejileri, yöntemleri, yönetimleri ve uygulamaları küresel ekonomiyi, küresel ticareti ve diğer ülkelerin inovasyon ve lojistik konusundaki stratejilerini, yöntemlerini ve faaliyetlerini hassasiyetle etkileyebilmektedir. Dolayısıyla bu durum, dünya ekonomisi ile dünya ticareti gelişimleri ve diğer ülkelerin inovasyon ve lojistik faaliyetlerinin, G7 ülkelerinin inovasyon ve lojistik faaliyetlerine göre türevinin fazla olmasına neden olabilmektedir. Diğer bir ifade ile dünya ekonomisi ile dünya ticareti gelişimleri ve diğer ülkelerin inovasyon ve lojistik faaliyetlerinin değişimi, G7 ülkelerinin inovasyon ve lojistik faaliyetlerindeki değişimine olan oranı fazladır. Bu kapsamda G7 ülkelerinin inovasyon ve lojistik verilerine göre bütünsel anlamda inovasyon ve lojistik boyutları ile söz konusu boyutların bileşenleri arasındaki ilişkisel yapıların tespit edilmesi önem kazanmaktadır. Bunlara bağlı olarak araştırmanın amaçları kapsamında araştırmada G7 ülkelerinin inovasyon ve lojistik performans değerleri dikkate alınmıştır.

\subsection{Araştırmanın Önemi ve Katkısı}

Ulusal ve uluslararası literatür incelendiğinde, araştırmada belirtilen yıllara ait raporlar dahilinde G7 ülkelerinin küresel inovasyon ve lojistik performans endekslerini belirleyen bileşenlere ait değerler kapsamında inovasyon ve lojistik boyutları arasındaki ilişkilerin çok yönlü olarak analizine yönelik bir araştırmaya rastlanılmamıştır. Bu kapsamda bu araştırma, belirtilen özelliklere uyan litaratürde bulunan ilk araştırmadır. Ayrıca bu araştırma, inovasyon ve lojistik ilişkisini inceleyecek olan araştırmacılar için veri seti niteliği kazanmaktadır. Teknik anlamda ise bu araştırma, iki boyut arasında ilişkide boyutlara ait değişkenlerin ilişkiye katkı niceliğinin tespit edilmesine ve ilişkilerin çok yönlü olarak değerlendirilmesine yönelik bir yöntem niteliği taşımaktadır.

\section{Bulgular}

\subsection{Bileşenlerin İnovasyon ve Lojistik Boyutları Arasındaki ilişkisel Yapıya Katkı Dereceleri}

Inovasyon ve lojistik bileşenlerinin birbirleri arasındaki ilişki değerlerini ölçmek için bileşenlerin normallik testinin yapılması gerekmektedir. Söz konusu bileşenlerin normal dağılımını durumunun tespiti için Kogmagrov-Smirnov ve Shapiro Wilk testi uygulanmıştır. Bu teste göre tespit edilen değerler Tablo 4'de sunulmuştur. 
Tablo 4. Bileşenlerin Normallik Testi

\begin{tabular}{|c|c|c|c|c|c|c|}
\hline \multirow{2}{*}{ Bileşenler } & \multicolumn{3}{|c|}{ Kolmogorov-Smirnov } & \multicolumn{3}{c|}{ Shapiro-Wilk } \\
\cline { 2 - 7 } & Değer & df & $\mathbf{p}$ & Değer & df & $\mathbf{p}$ \\
\hline Kie1 & 0,108 & 35 & 0,200 & 0,964 & 35 & 0,310 \\
\hline Kie2 & 0,194 & 35 & 0,090 & 0,880 & 35 & 0,110 \\
\hline Kie3 & 0,078 & 35 & 0,200 & 0,978 & 35 & 0,691 \\
\hline Kie4 & 0,112 & 35 & 0,200 & 0,967 & 35 & 0,376 \\
\hline Kie5 & 0,139 & 35 & 0,084 & 0,958 & 35 & 0,193 \\
\hline Kie6 & 0,110 & 35 & 0,200 & 0,939 & 35 & 0,054 \\
\hline Kie7 & 0,081 & 35 & 0,200 & 0,978 & 35 & 0,688 \\
\hline Lpe1 & 0,110 & 35 & 0,200 & 0,970 & 35 & 0,432 \\
\hline Lpe2 & 0,092 & 35 & 0,200 & 0,974 & 35 & 0,549 \\
\hline Lpe3 & 0,068 & 35 & 0,200 & 0,981 & 35 & 0,778 \\
\hline Lpe4 & 0,086 & 35 & 0,200 & 0,977 & 35 & 0,675 \\
\hline Lpe5 & 0,150 & 35 & 0,087 & 0,936 & 35 & 0,063 \\
\hline Lpe6 & 0,100 & 35 & 0,200 & 0,970 & 35 & 0,457 \\
\hline
\end{tabular}

Kogmagrov-Smirnov ve Shapiro Wilk testinde değişkenlerin normal dağılım özelliğine sahip olması için ilgili değişkenlerin testlere ilişkin anlamlılık değerlerinin (p) 0,05'den büyük olması gerekmektedir (Kalaycl, 2013). Tablo 4'e göre, tüm bileşenlerin Kogmagrov-Smirnov ve Shapiro Wilk test değerlerinin anlamlılık değerleri 0,05 değerinden büyük çıktığı ( $p_{\text {Bileşenler }>.05)}$ için bileşenlere ait verilerin normal dağıldığı değerlendirilebilir. Bu çerçevede bileşenler normal dağıldığı için bileşenler arasındaki ilişkiler parametrik bir test olan Pearson korelasyon testi ile ölçülmüştür. Bu anlamda bileşenler arasındaki ilişkiler Tablo 5'de sunulmuştur.

Tablo 5. Bileşenler Arasındaki Pearson İlişki Katsayı Değerleri

\begin{tabular}{|c|c|c|c|c|c|c|c|c|}
\hline \multicolumn{2}{|c|}{ Bileşenler } & GLpe1 & GLpe2 & GLpe3 & ÇLpe4 & ÇLpe5 & ÇLpe6 & Ortalamalar \\
\hline \multirow{2}{*}{ GKie1 } & Değer & $0,475^{* *}$ & $0,361^{*}$ & $0,474^{* *}$ & 0,257 & 0,002 & $0,403^{*}$ & 0,329 \\
\cline { 2 - 8 } & $\mathbf{p}$ & 0,004 & 0,033 & 0,004 & 0,136 & 0,990 & 0,016 & ------ \\
\hline \multirow{2}{*}{ GKie2 } & Değer & $0,695^{* *}$ & $0,654^{* *}$ & $0,693^{* *}$ & $0,615^{* *}$ & $0,353^{*}$ & $0,716^{* *}$ & 0,621 \\
\cline { 2 - 8 } & $\mathbf{p}$ & 0,000 & 0,000 & 0,000 & 0,000 & 0,037 & 0,000 & ------ \\
\hline \multirow{2}{*}{ GKie3 } & Değer & $0,427^{*}$ & 0,275 & $0,356^{*}$ & 0,167 & $0,340^{*}$ & $0,367^{*}$ & 0,322 \\
\cline { 2 - 9 } & $\mathbf{p}$ & 0,011 & 0,109 & 0,036 & 0,339 & 0,046 & 0,030 & ------ \\
\hline \multirow{2}{*}{ GKie4 } & Değer & 0,274 & 0,241 & 0,281 & 0,133 & $-0,181$ & $0,475^{* *}$ & 0,264 \\
\cline { 2 - 9 } & $\mathbf{p}$ & 0,111 & 0,163 & 0,103 & 0,448 & 0,297 & 0,004 & ------ \\
\hline \multirow{2}{*}{ GKie5 } & Değer & $0,335^{*}$ & $0,387^{*}$ & $0,400^{*}$ & 0,222 & 0,152 & $0,416^{*}$ & 0,319 \\
\cline { 2 - 9 } & $\mathbf{p}$ & 0,049 & 0,022 & 0,017 & 0,199 & 0,383 & 0,013 & ------ \\
\hline \multirow{2}{*}{ ÇKie6 } & Değer & $0,541^{* *}$ & $0,610^{* *}$ & $0,588^{* *}$ & $0,462^{* *}$ & 0,220 & $\mathbf{0 , 7 2 6} 6^{* *}$ & 0,525 \\
\cline { 2 - 8 } & $\mathbf{p}$ & 0,001 & 0,000 & 0,000 & 0,005 & 0,204 & 0,000 & ------ \\
\hline \multirow{2}{*}{ ÇKie7 } & Değer & $0,562^{* *}$ & $0,466^{* *}$ & $0,528^{* *}$ & $0,573^{* *}$ & $0,405^{*}$ & $0,580^{* *}$ & 0,519 \\
\cline { 2 - 8 } & $\mathbf{p}$ & 0,000 & 0,005 & 0,001 & 0,000 & 0,016 & 0,000 & ------ \\
\hline \multicolumn{2}{|c|}{ Ortalamalar } & 0,473 & 0,428 & 0,474 & 0,347 & 0,184 & 0,526 & ------ \\
\hline
\end{tabular}

İnovasyon Girdi Bileşenlerin ilişkiler Ortalaması=0,371, İnovasyon Çıktı Bileşenlerin İlişkiler Ortalaması=0,519, Lojistik Girdi Bileşenlerin ilişkiler Ortalaması=0,458, Lojistik Çıktı Bileşenlerin Iilişkiler Ortalaması=0,352.

$*=p<.01, * *=p<.05$ 
Tablo 5'e göre, inovasyon ve lojistik bileşenleri arasındaki tüm ilişkilerin pozitif yönlü olduğu tespit edilmiştir. Bunun yanında inovasyon ve lojistik bileşenleri arasındaki çoğu ilişki genel anlamda anlamlı $\left(^{*}=p<0,01,{ }^{* *}=p<0,05\right)$ ve orta düzeyde olduğu tespit edilmiştir. Özellikle beşeri sermaye altyapı (GKie2) ve takip ve izleme (ÇLpe6) bileşenleri ile bilgi ve teknoloji çıktısı (GKie6) ve takip ve izleme (ÇLpe6) bileşenlerinin kendi aralarındaki ilişki seviyeleri yüksek düzeydedir $\left(\mathrm{p}_{\text {GKie2-çıpe }}=0,716, \mathrm{p}_{\text {çKiee-çıpe }}=0,726\right)$. Ayrıca beşeri sermaye ve araştırma (GKie2) ve gümrükler (GLpe1) ile beşeri sermaye ve araştırma (GKie2) ve lojistik kalite ve yetkinlik (GLpe3) bileşenlerinin kendi arasındaki ilişkiler yüksek seviyeye yakın değerde olduğu tespit edilmiştir ( $p_{\text {GKie2-GLpe1 }}=0,695, p_{\text {GKie2-GLpe3 }}=0,693$ ). Dolayısıyla Tablo 5'e göre, beşeri sermaye altyapı (GKie2) ile takip ve izleme (ÇLpe6), bilgi ve teknoloji çıktısı (ÇKie6) ile takip ve izleme (ÇLpe6), beşeri sermaye ve araştırma (GKie2) ile gümrükler (GLpe1) ve beşeri sermaye ve araştırma (GKie2) ile lojistik kalite ve yetkinlik (GLpe3) bileşenleri arasındaki ilişkiler genel anlamda inovasyon ve lojistik boyutu arasındaki ilişkiye en fazla katkı sağlayan ilişkiler olduğu değerlendirilebilir. Dolayısıyla beşeri sermaye altyapı (GKie2) ve takip ve izleme (ÇLpe6), bilgi ve teknoloji çıktısı (GKie6) ve takip ve izleme (ÇLpe6), beşeri sermaye ve araştırma (GKie2) ve gümrükler (GLpe1) ile beşeri sermaye ve araştırma (GKie2) ve lojistik kalite ve yetkinlik (GLpe3) bileşenlerinin kendi arasındaki ilişkilerin yüksek seviye değerinde veya yüksek seviyeye yakın değerde olmaları, G7 ülkelerinin söz konusu bileşenlerin birbirlerini ilgilendirecek veya ortak faaliyetleri daha fazla sağladıklarını göstermektedir.

Değişkenler arası ilişkilerde, değişkinlerin birbirlerine olan ilişki değerlerinin ortalamaları hesaplanarak söz konusu değişkenlerin ilişkisel yapıya olan katkı değerleri tespit edilebilmektedir (Altıntaş, 2020: 306). Tablo 5'de inovasyon ve lojistik bileşenlerinin inovasyon ve lojistik boyutları arasındaki ilişkisel yapıya katkı seviyelerini tespiti, her bir inovasyon bileşeninin lojistik bileşenlerine olan ilişki değerlerinin ve her bir lojistik bileşeninin inovasyon bileşenlerine olan ilişki değerlerinin ortalamaları alınarak hesaplanmıştır. Buna göre, bileşenlerin inovasyon ve lojistik boyutları arasındaki ilişki durumuna katkı seviyeleri beşeri sermaye ve araştırma (GKie2=0,621-orta düzey), takip ve izleme (ÇLpe6=0,526-orta düzey), bilgi ve teknoloji çıktısı (ÇKie6=0,525-orta düzey), yaratıcı çıktısı (ÇKie7=0,519-orta düzey), lojistik kalite ve yetkinlik (GLpe3=0,474-orta düzeye yakın), gümrükler (GLpe1=0,473-orta düzeye yakın), altyapı-lojistik (GLpe2=0,428düşük düzey), zamanlama (ÇLpe4=0,347-düşük düzey), kurumlar (GKie1=0,329-düşük düzey), altyapıinovasyon (GKie3=0,322-düşük düzey), iş gelişmişliği (GKie5=0,319-düşük düzey), pazar gelişmişliği (GKie4=0,264-düşük düzey) ve uluslararası sevkiyatlar (ÇLpe5=0,184-düşük düzey) olarak sıralanmıştır. Bulgulara göre, özellikle beşeri sermaye ve araştırma (GKie2), takip ve izleme (ÇLpe6), bilgi ve teknoloji çıktısı (ÇKie6), yaratıcı çıktısı (ÇKie7) diğer bileşenlere göre inovasyon ve lojistik boyutları arasında ilişkinin sağlanmasına yönelik katkılarının fazla olması, G7 ülkelerin söz konusu belirtilen bileşenler ile ilgili olarak inovasyon ve lojistik boyutlarının birbirlerini sağlamasında diğer bileşenlere göre daha kapsamlı ve ayrıntılı çalışmaların yaptığını göstermektedir.

Tablo 5'e göre, inovasyon çıktı bileşenlerin ilişki ortalaması, inovasyon girdi bileşenlerinin ilişki ortalamasından yüksek değerde çıktığı için inovasyon çıktı bileşenlerinin inovasyon girdi bileşenlerine göre inovasyon ve lojistik boyutu arasındaki ilişkisel yapıya daha fazla katkı sağladıkları tespit edilmiştir (içBiO=0,519>іGGiO=0,371). Aynı şekilde lojistik girdi bileşenlerinin ilişkiler ortalaması, lojistik çıktı bileşenlerinin ilişkiler ortalamasından yüksek çıktığı için lojistik çıktı bileşenleri lojistik girdi bileşenlerine göre inovasyon ve lojistik boyutu arasındaki ilişkisel yapıya daha fazla katkı sağlamışlardır. (LGBIO=0,519>LÇBiO=0,371). Girdi ve çıktılar arasındaki ilişkiler kapsamında, inovasyon ve lojistik boyutları arasındaki ilişkiye katkı sağlama değerleri sırasıyla inovasyon çıktı bileşenleri $(0,519)$, lojistik girdi bileşenleri $(0,458)$, inovasyon girdi bileşenleri $(0,371)$ ve lojistik çıktı bileşenleri $(0,352)$ olarak sıralanmıştır. Dolayısıyla bu sonuçlara göre, G7 ülkeleri inovasyon ve lojistik boyutlarının birbirlerini tamamlamaları açısından inovasyon boyutu kapsamında çıktı bileşenleri çerçevesinde inovasyon faaliyetlerinde sonuç odaklı yaklaşımlara, lojistik boyutu kapsamında ise girdi bileşenleri çerçevesinde temel odaklı yaklaşımlara daha fazla önem verdiği değerlendirilebilir. 


\section{2 İnovasyon ve Lojistik Boyutları Arasındaki İlişkinin Kanonik Korelasyon Hesabı ile Tespit}

\section{Edilmesi}

Inovasyon ve lojistik boyutu arasındaki kanonik ilişkinin ölçülmesinde ilk olarak Tablo 3'de veri setinde belirtilen inovasyon ve lojistik kümeleri oluşturularak söz konusu kümeleri oluşturan bileşenlerin birbirleri ile olan ilişkilerine istinaden inovasyon ve lojistik boyutları arasında kanonik fonksiyonlar oluşturulmuştur. Tespit edilen kanonik fonksiyonlara ait değerler Tablo 6'da açıklanmıştır.

Tablo 6. Inovasyon ve Lojistik Boyutları Arasındaki Kanonik Fonksiyonlara Ait Değerler

\begin{tabular}{|c|c|c|c|c|c|c|}
\hline Fonksiyonlar & $\begin{array}{c}\text { Boyutlar Arası Korelasyon } \\
\text { Katsayıları }\end{array}$ & $\begin{array}{c}\text { Korelasyon } \\
\text { Kareleri }\end{array}$ & $\begin{array}{c}\text { Wilk's } \\
\text { Lambda }\end{array}$ & Ki-Kare $\mathbf{X}^{2}$ & Df & $\mathbf{p}$ \\
\hline $\mathbf{1}$ & $\mathrm{C}_{1}=0,932^{*}$ & $\mathrm{C}_{1}{ }^{2}=0,869$ & 0,021 & 103,688 & 42,000 & 0,000 \\
\hline $\mathbf{2}$ & $\mathrm{C}_{2}=0,746^{* *}$ & $\mathrm{C}_{2}{ }^{2}=0,557$ & 0,164 & 48,8360 & 30,000 & 0,016 \\
\hline $\mathbf{3}$ & $\mathrm{C}_{3}=0,625$ & $\mathrm{C}_{3}{ }^{2}=0,391$ & 0,369 & 26,9110 & 20,000 & 0,138 \\
\hline $\mathbf{4}$ & $\mathrm{C}_{4}=0,529$ & $\mathrm{C}_{4}{ }^{2}=0,280$ & 0,605 & 13,5520 & 14,000 & 0,330 \\
\hline $\mathbf{5}$ & $\mathrm{C}_{5}=0,386$ & $\mathrm{C}_{5}{ }^{2}=0,149$ & 0,840 & 4,69400 & 6,000 & 0,584 \\
\hline $\mathbf{6}$ & $\mathrm{C}_{6}=0,110$ & $\mathrm{C}_{6}{ }^{2}=0,012$ & 0,998 & 0,32600 & 2,000 & 0,850 \\
\hline
\end{tabular}

${ }^{*}=p<0,01,{ }^{* *}=p<0,05$

Tablo 6'ya göre, inovasyon ve lojistik boyutları arasında ilişkileri açıklayan toplam 6 fonksiyon oluşmuştur. Tablo 6'ya göre, birinci fonksiyon için inovasyon ve lojistik boyutları arasındaki kanonik ilişki katsayısı anlamlı $\left(p_{C_{1}}=0,00<0,01\right)$, pozitif yönde ve çok yüksek seviyede $\left(C_{1}=0,932\right)$, ikinci fonksiyon için inovasyon ve lojistik boyutları arasındaki kanonik ilişki katsayısı ise anlamlı $\left(p_{\mathrm{c} 2}=0,016<0,05\right)$, pozitif yönde ve yüksek seviyede $\left(C_{2}=0,746\right)$ olduğu tespit edilmiştir. 1 . ve 2 . fonksiyonlar haricinde diğer 4 fonksiyonda inovasyon ve lojistik boyutları arasındaki ilişkiler anlamlı olmadığı için sadece 1 . ve 2 . fonksiyonlarda belirtilen kanonik değerler dikkate alınmıştır.

Kanonik korelasyon katsayısının karesi veya setler arası korelasyonun karesi fonksiyonların varyans miktarını verir. Tablo 6'ya göre, toplam varyans miktarı 1 . fonksiyon için $0,869,2$. fonksiyon 0,557 olarak hesaplanmıştır. Bunun yanında Wilk's Lambda, toplam varyansın değişkenler arasındaki farklar tarafından açıklanamayan kısmını gösterir. Ayrıca Wilk's Lambda, her bir kanonik fonksiyonun özdeğer istatistiğinin anlamlılığını test eder. Wilk's Lambda'nın 1 değerine yaklaşması, kanonik fonksiyonun anlamlılık kalitesinin azalmasına ve ki-kare değerinin düşmesine neden olur. Bu anlamda kanonik korelasyonlarının anlamlılığını test etmek için Wilk's Lambda istatistiğinden yararlanılır. Bu kapsamda toplam varyansın değişkenler arasındaki farklar tarafından açıklanma oranı birinci fonksiyon için \%97,9, ikinci fonksiyon için \%83,6 olarak tespit edilmiştir. Dolayısıyla Tablo 6'ya göre, 1. ve 2. kanonik fonksiyonların Wilk's Lambda değerlerinin 1 değerinden uzak olmaları, fonksiyonların ki-kare (1. fonksiyon $X^{2}=103,688$, 2. fonksiyon $X^{2}=48,8360$ ) ve serbestlik değerlerinin ( $\mathrm{df}_{\text {Fonksiyon } 1}=42,000, \mathrm{df}_{\text {Fonksiyon } 2}=30,000$ ) yüksek, anlamlılık düzeylerinin yüksek olmasına neden olmuştur.

Kanonik korelasyon analizinde gereksizlik hesabı (redundancy analysis) bir boyuttaki (setteki) değişkenlerin kendi boyutundaki (setindeki) ve ilişkili olduğu diğer boyuttaki (setteki) varyansı hangi oranda açıkladığını göstermektedir. Bu anlamda gereksizlik ölçüsü, bir boyuttaki (setteki) bileşenlere ait kanonik yüklerin varyansının diğer boyuttaki (setteki) bileşenler tarafından yüzde olarak çıkarımını açıklamaktadır. Diğer bir ifade ile gereksizlik ölçütü, bir boyuttaki (setteki) değişmelerin belirli bir yüzde oranı değerinde diğer boyuttaki (setteki) bileşenler tarafından açıklandığını belirtmektedir. Böylelikle 2 boyut (set) arasındaki ilişkide boyutların birbirlerini etkileme değerleri ve söz konusu boyutlar arasındaki ilişkisel yapıya daha çok katkı sağlayan boyutun (setin) tespiti yapılabilmektedir. Bu kapsamda boyutların değişkenlerinin (bileşenlerinin) kendi boyutundaki (setindeki) ve ilişkide olduğu diğer boyutlardaki (setlerdeki) varyansı açıklama oranları (gereksizlik ölçümü değerleri) Tablo 7'de sunulmuştur. 
Tablo 7. Gereksizlik Ölçümü Değerleri

\begin{tabular}{|c|c|c|c|c|}
\hline Fonksiyonlar & $\begin{array}{c}\text { inovasyon } \\
\text { Bileşenlerin Kendi } \\
\text { Boyutundaki Varyansı } \\
\text { Açıklama Oranı }\end{array}$ & $\begin{array}{c}\text { Inovasyon } \\
\text { Bileşenlerin Lojistik } \\
\text { Boyutundaki Varyansı } \\
\text { Açıklama Oranı }\end{array}$ & $\begin{array}{c}\text { Lojistik } \\
\text { Bileşenlerin Kendi } \\
\text { Boyutundaki Varyansı } \\
\text { Açıklama Oranı }\end{array}$ & $\begin{array}{c}\text { Lojistik } \\
\text { Bileşenlerin inovasyon } \\
\text { Boyutundaki Varyansı } \\
\text { Açıklama } \\
\text { Oranı }\end{array}$ \\
\hline $\mathbf{1}$ & 0,291 & 0,603 & 0,694 & 0,252 \\
\hline $\mathbf{2}$ & 0,194 & 0,144 & 0,080 & 0,108 \\
\hline $\mathbf{3}$ & 0,088 & 0,020 & 0,052 & 0,035 \\
\hline $\mathbf{4}$ & 0,103 & 0,017 & 0,061 & 0,020 \\
\hline $\mathbf{5}$ & 0,085 & 0,013 & 0,085 & 0,013 \\
\hline $\mathbf{6}$ & 0,141 & 0,000 & 0,028 & 0,002 \\
\hline
\end{tabular}

Tablo 7’ye göre, 6 kanonik fonksiyon kapsamında 1. ve 2. kanonik fonksiyonlar anlamlı çıktığı için 1. ve 2. kanonik fonksiyonlara ait gereksizlik hesapları dikkate alınmıştır. Tablo 7’ye göre, 1 . fonksiyon için lojistik bileşenlerinin kendi boyutundaki varyansı açıklama oranı, 2. fonksiyon için ise inovasyon bileşenlerinin kendi boyutundaki varyansı açıklama oranı diğer varyans açıklama oranlarına göre daha fazla olduğu tespit edilmiştir. Ayrıca Tablo 7'ye göre, 1. ve 2. fonksiyonlar için inovasyon bileşenlerinin lojistik boyutundaki varyansı açıklama oranları, lojistik bileşenlerin inovasyon boyutundaki varyansı açıklama oranlarından fazla olduğu için inovasyon boyutu lojistik boyutunu, lojistik boyutunun inovasyon boyutunu etkilediğinden daha fazla pozitif yönde etkilemiştir (İnovasyon: 1. Fonksiyon=0,603> Lojistik: 1. Fonksiyon= 0,252, Inovasyon: 2. Fonksiyon=0,144> Lojistik: 2 . Fonksiyon=0,108). Dolayısıyla inovasyon ve lojistik boyutu arasındaki karşılıklı ilişkisel yapıya inovasyon boyutu lojistik boyutuna göre daha fazla katkı sağlamıştır. Dolayısıyla bu durum, G7 ülkelerinin lojistik boyutun inovasyon boyutunu sağlamasından daha çok, inovasyon boyutunun lojistik boyutunu sağlamasına yönelik daha fazla faaliyetlerde bulunduğunu göstermektedir. Böylelikle G7 ülkeleri, inovasyon ve lojistik boyutlarının birbirlerini sağlamaları açısından inovasyon boyutunun lojistik boyutu üzerinde daha fazla onarıcı girişimlerde bulunmuşlardır.

\section{Sonuç}

Araştırmanın kavramsal çerçeve ve literatür kısmında inovasyon, küresel inovasyon endeksi, lojistik, lojistik performans endeksi, inovasyon ve lojistik boyutları ilişkisi ve inovasyon ve lojistik boyutları ilişkisine yönelik literatürde bulunan araştırmalar ile ilgili olarak açıklamalarda bulunulmuştur. Araştırmanın birinci amacı, G7 ülkelerinin inovasyon ve lojistik bileşenlerine ait 2010, 2012, 2014 ve 2018 yıllarının değerleri kapsamında inovasyon ve lojistik boyutlar arasındaki ilişkisel yapıya yüksek düzeyde katkı sağlayan inovasyon ve lojistik bileşenlerinin ilişki durumlarının ve bileşenlerin ilişkiye katkı sağlama değerlerini tespit etmektir. Araştırmanın ikinci amacı ise G7 ülkelerine ait veriler kapsamında bütünsel anlamda inovasyon ve lojistik boyutlar arasındaki ilişki yapısını ve ilişkisel yapıya en çok katkı sağlayan boyutu tespit etmektir. Araştırmada birinci amacını belirlemek için inovasyon ve lojistik bileşenlerine ait veriler normal dağılım gösterdiği için değişkenler arasındaki parametrik ilişki değerini belirleyen Pearson ilişki katsayısı kullanıımıştır. Araştırmanın ikinci amacını belirlemek için ise kanonik korelasyon yönteminden yararlanılmıştır.

Bulgulara göre, inovasyon ve lojistik bileşenleri arasındaki ilişkilerin hepsi pozitif yönlü olduğu tespit edilmiştir. Ayrıca inovasyon ve lojistik bileşenleri arasındaki çoğu ilişkiler anlamlı ve orta düzeydedir. Bulgulara göre, beşeri sermaye altyapı (GKie2) ile takip ve izleme (ÇLpe6), bilgi ve teknoloji çıktısı (ÇKie6) ile takip ve izleme (ÇLpe6) bileşenleri arasındaki ilişkiler yüksek düzeyde, beşeri sermaye ve araştırma (GKie2) ile gümrükler (GLpe1), beşeri sermaye ve araştırma (GKie2) ile lojistik kalite ve yetkinlik (GLpe3) bileşenleri arasındaki ilişkiler ise yüksek düzeye yakın değerde oldukları için söz konusu ilişkiler genel anlamda inovasyon ve lojistik boyutu arasındaki ilişkiye en fazla katkı sağlayan ilişki durumları olduğu tespit edilmiştir. Buna göre, inovasyon ve lojistik performansların sağlanmasında yüksek veya yüksek düzeye yakın pozitif yönlü inovasyon ve lojistik bileşenlerinin ilişkileri, diğer inovasyon ve lojistik bileşenlerinin birbirleri arasındaki ilişkilere göre 
inovasyon ve lojistik performanslarının sağlanmasında birbirlerini daha çok tamamladıkları ve inovasyon ile lojistik performanslarının sağlanmasında daha çok fonksiyonel yapılarının olduğu değerlendirilmiştir. Bunun nedeni, G7 ülkelerinin inovasyon ve lojistik uygulamalarında birbirlerini tamamlayacak fazla faaliyetler sağlamasından kaynaklanmaktadır. Bunun yanında, inovasyon ve lojistik boyutlarının yüksek düzeyde pozitif yönde birbirlerini tamamlaması, inovasyon ve lojistik performanslarının artmasına neden olabilmektedir. Ayrıca G7 ülkelerinin belirli bir ekonomik gelişmişliğe ve büyüklüğe sahip olması ve inovasyon ile lojistik performanslarının ekonomik gelişmişliğe ve büyüklüğe olumlu etkileri düşünüldüğünde, inovasyon ve lojistik performansların sağlanmasında yüksek veya yüksek düzeye yakın pozitif yönlü inovasyon ve lojistik boyutu arasındaki ilişkiler, diğer inovasyon ve lojistik bileşenlerinin birbirleri arasındaki ilişkilere göre daha fazla ekonomik gelişmişliğe ve büyüklüğe katkı sağladığı değerlendirilebilir.

Araştırma sonuçlarına istinaden inovasyon ve lojistik boyutları arasındaki ilişkisel yapıya en fazla katkı sağlayan inovasyon ve lojistik bileşenleri beşeri sermaye ve araştırma (GKie2=0,621-orta düzey), takip ve izleme (ÇLpe6=0,526-orta düzey), bilgi ve teknoloji çıktısı (ÇKie6=0,525-orta düzey), yaratıcı çıktısı (ÇKie7=0,519-orta düzey), lojistik kalite ve yetkinlik (GLpe3=0,474-orta düzeye yakın), gümrükler (GLpe1=0,473-orta düzeye yakın) olarak tespit edilmiştir. Bu durum G7 ülkelerinin, genel anlamda inovasyon ve lojistik faaliyetlerin geliştirilmesinde ve performanslarının sağlanmasında söz konusu inovasyon ve lojistik boyutları arasındaki ilişkisel yapıya en fazla katkı sağlayan inovasyon ve lojistik bileşenlerine daha fazla önem verdiğini göstermektedir. İnovasyon ve lojistik boyutlarının yüksek düzeyde pozitif yönde birbirlerini tamamlaması, inovasyon ve lojistik performanslarının artmasına neden olması ile inovasyon ve lojistik performanslarının sağlanmasının ekonomik gelişmişliğe ve büyüklüğe olan pozitif etkileri düşünüldüğünde, bulgulara göre lojistik faaliyetlerin performansının oluşmasında beşeri sermaye ve araştırma (GKie2), bilgi ve teknoloji çıktısı (ÇKie6), yaratıcı çıktısı (ÇKie7) inovasyon bileşenleri, lojistik faaliyetlerin performansının oluşmasında ise takip ve izleme (ÇLpe6), lojistik kalite ve yetkinlik (GLpe3) ve gümrükler (GLpe1=0,473) lojistik bileşenleri diğer inovasyon ve lojistik bileşenlerine göre daha etkili olduğu değerlendirilmiştir.

Tespit edilen nicel değerler kapsamında, inovasyon çıktı bileşenlerin ilişki ortalaması, inovasyon girdi bileşenlerinin ilişki ortalamasından yüksek değerde tespit edilmesinden dolayı inovasyon çıktı bileşenleri inovasyon girdi bileşenlerine göre genel anlamda lojistik bileşenlerini daha fazla tamamladığı değerlendirilmiştir (IÇBiO>IGBiO). Bunun nedeni, G7 ülkelerinin sonuç odaklı yaklaşım çerçevesinde inovasyon stratejilerini ve yöntemlerini belirleyerek inovasyon faaliyetlerini tamamladıklarını ve sağlanan veya sağlanacak olan inovasyon performansı ile lojistik faaliyetlerini anlamlı, etkili, etkin ve verimli olmalarını için girişimlerde bulunmalarından ya da bulunabilecek olmalarından kaynaklanabilir. Lojistik girdi bileşenlerinin ilişkiler ortalaması, lojistik çıktı bileşenlerinin ilişkiler ortalamasından yüksek çıkmasından dolayı lojistik çıktı bileşenleri inovasyon ve lojistik boyutu arasındaki ilişkisel yapıya daha fazla katkı sağlamıştır (LGBiO>LÇBiO). Bu durumun temel nedeni ise G7 ülkelerine göre lojistik girdi bileşenlerinin lojistik çıktı bileşenlerine göre lojistik konularında inovasyon faaliyetlerin oluşmasında daha temel bir yapıya sahip olmasından, lojistik girdi bileşenlerinin lojistik bileşenlerini ilgilendiren faaliyetlerinin ve ortak noktalarının daha fazla bulunmasından ve lojistik girdi bileşenlerinin lojistik çıktı bileşenlerinin moderatör bileşenler olmasına gerek duyulmadan inovasyon bileşenleri ile doğrudan ilişki kurmasından kaynakladığı değerlendirilebilir.

Araştırmada tespit edilen diğer bir bulgu çerçevesinde, bütünsel anlamda inovasyon boyutunun lojistik boyutunu etkileme değeri, lojistik boyutunun inovasyon boyutuna olan etkileme değerinden daha fazla olduğu tespit edilmiştir. Bu durum, inovasyon ve lojistik boyutların birbirlerini tamamlamasında ve pozitif yönlü ilişki kurmasında inovasyon boyutu lojistik boyutuna göre daha fazla katkı sağladığını göstermektedir. Bunun sebebi ise G7 ülkelerinin inovasyon ve lojistik boyutları arasındaki ilişkinin sağlanmasına bağlı olarak ekonomik gelişme ve büyüme için lojistik faaliyetleri performanslarının oluşmasından ve gelişmesinden önce inovasyon faaliyetlerinin gelişmesi ve performanslarının sağlanmasına önem ve öncelik vermelerinden ve inovasyon faaliyetlerini lojistik faaliyetlerine göre onarıcı fonksiyon çerçevesinde daha kapsamlı ve fazla yapmalarından kaynaklandığı değerlendirilmiştir. Dolayısıyla genel anlamda G7 ülkelerine göre yapılan inovatif faaliyetlerle lojistik konularında daha çok uzmanlaşarak, gelişerek 
ve buna bağlı olarak belirli bir lojistik performansının sergilenebilerek oluşabilecek olan lojistik uğraşılarının inovasyon faaliyetlerini artırabileceği değerlendirilmiştir.

Literatür değerlendirildiğinde, inovasyon boyutunun lojistik boyutunu ve lojistik boyutunun inovasyon boyutunu sağladığı tespit edilmiştir. Dolayısıyla bu çalışma, inovasyon ve lojistik boyutlarının birbirlerini sağlamaları açısından literatürdeki açıklamalar ile tutarlılık göstermiş olup, inovasyon ve lojistik boyutlarının birbirleri arasındaki ilişkilerin pozitif yönlü ve anlamlı olmasına yönelik ampirik bir sonuç elde edilmesi çerçevesinde literatüre katkı sağladığı düşünülmektedir. Bunun yanında bu çalışma, ülkelerin inovasyon ve lojistik performansları arasındaki ilişkilerin ölçülmesi kapsamında Burmaoğlu'nun (2012), Erkan'ın (2014), Witkowski'nin (2017) ve Şipol ve Bizoi'nin (2010) çalışmalarına benzerlik göstermiştir.

$\mathrm{Bu}$ araştırma genel anlamda G7 ülkelerine ait inovasyon ve lojistik verilerine istinaden inovasyon ve lojistik boyutlarının birbirleri ile olan ilişkilerin çok yönlü olarak değerlendirilmesine yönelik araştırmacılar için bir veri seti niteliği taşımaktadır. Öncelikle ülkeler lojistik ve inovasyon bileşenlerinin birbirlerini ilgilendirecek ve tamamlayacak faaliyetleri oluşturması gerekmektedir. Böylelikle inovasyon ve lojistik boyutları arasında anlamlı, pozitif yönlü ve yüksek düzeyde ilişkiler oluşacaktır. Bu durum ilgili ülkeler için inovasyon ve lojistik performanslarııın artmalarına, inovasyon ile lojistik boyutlarının daha anlamlı olmasına ve söz konusu boyutların sinerji kapasitelerinin artmasına neden olabilecektir.

İnovasyon ve lojistik boyutları arasındaki ilişki çok boyutlu olarak düşünülerek söz konusu ilişkinin ve boyutların birbirlerini tamamlama derecelerinin ülkelerin yaşam kalitelerini, yaşam standartlarını ve refah düzeylerini belirleyen değişkenler ile ilişkilendirilebilir. Böylelikle inovasyon ve lojistik boyutlarının oluşturacağı ilişkilerin diğer boyutlar üzerindeki ilişkileri değerlendirilebilecektir. Bunun yanında, inovasyon ve lojistik boyutlarının çok ayrıntılı olarak değerlendirilmesi kapsamında söz konusu boyutların bileşen veya değişken sayısı artırılabilir veya ülkelere özgü inovasyon ve lojistik değişkenleri oluşturulabilir. Dolayısıyla ülkelerin inovasyon ve lojistik boyutları arasındaki ilişki oluşturma kapasitesi daha gerçekci açıklanabilir.

Inovasyon ve lojistik boyutlarında her boyutun ayrı olarak kendi bileşenleri de birbirlerini tamamlamaktadır. Bu kapsamda sadece heterojen bir yapıda inovasyon ve lojistik bileşenleri arasındaki ilişkiler değil, bunun yanında ilişki yapıları homojen olarak (her bir boyuta ait değiş̧enlerin kendi aralarındaki ilişkiler) tespit edilerek bütünsel anlamda inovasyon ve lojistik boyutları arasındaki ilişki yapıları çok boyutlu olarak değerlendirilebilir. Böylelikle ülkeler açısından inovasyon ve lojistik boyutlarının ilişkisel güçleri bütünsel anlamda değerlendirilebilir. Ayrıca araştırmacılar için yıllara göre inovasyon ve lojistik boyutları arasındaki ilişkiler tespit edilerek meta analizi yöntemi kapsamında inovasyon ve lojistik boyutları arasındaki genel ilişki durumu ortaya çıkarılabilir ve inovasyon ile lojistik boyutları arasındaki ilişkiler yıllara göre değerlendirilerek sonuçlara göre nedensellik analizleri yapılabilir.

Teknik anlamda ise inovasyon ve lojistik bileşenleri arasındaki ilişkiler sadece pearson ve kanonik ilişki katsayıları ile değil, boyutlar arası ilişkileri belirleyen istatistiksel (yapısal eşitlik modellemesi, diğer ilişki katsayıları, etki katsayıları, lojistik regresyon, regresyon analizi vb.) ve sayısal yöntemler (dematel vb.) uygulanarak yöntemlere veya tekniklere göre tespit edilen sonuçların tutarlılıkları veya farklılıkları nedensel analizler çerçevesinde değerlendirilebilir.

\section{Beyan ve Açıklamalar (Disclosure Statements)}

1. Bu çalışmanın yazarı, araştırma ve yayın etiği ilkelerine uyduğunu kabul etmektedir (The author of this article confirms that her work complies with the principles of research and publication ethics).

2. Yazar tarafından herhangi bir çıkar çatışması beyan edilmemiştir (No potential conflict of interest was reported by the author).

3. Bu çalışma, intihal tarama programı kullanılarak intihal taramasından geçirilmiştir (This article was screened for potential plagiarism using a plagiarism screening program). 


\section{Kaynaklar}

Abu Bakar, M., Jaafar, H. S., Faisol, N., \& Muhammad, A. (2014). Logistic performans measurements: A disciriptive analysis. 6th International Conference on Logistics \& Transport, Kuala Lumpur, 1-7.

Akdoğan, Ş. (2017). Lojistik şirketlerin ilişki pazarlaması yönelimlerinin lojistik performans ve pazarlama performanslarına etkisi. Uluslararası Sosyal Araştırmalar Dergisi, 10(50), 621-633.

Alnıpak, S., \& Alkan, G. (2017). Sanayii 4.0'ın lojistik ve limancılık sektörüne etkileri. III. Ulusal Liman Kongresi, İzmir, 112.

Altıntaş, F. F. (2020). Sistem düşüncesi değişkenlerinin ilişkisel analizi. Social Sciences Studies Journal, 6(55), $301-310$.

Arvis, J. F., Ojala, L., Wiederer, C., Shepherd, B., Raj, A., Dairabayeva, K., Kiiski T. (2018). Connecting to compete 2018 trade logistics in the global economy the logistics performance index and its indicators. Washington: The International Bank for Reconstruction and Development/The World Bank.

Asdonk, J., Bredeweg, U., \& Kowol, U. (1991). Zur theorie und empirie der technikgenese am beispiel der produktionstechnik. Zeitschrift für Soziologie, 20(4), 290-304.

Ateş, i., \& Işık, E. (2010). Türkiye'nin lojistik hizmetlerinin gelişiminin ihracattaki büyümeye etkileri. Ekonomi Bilimleri Dergisi, 2(1), 99-106.

Ay Türkmen, M., \& Aynaoğlu, Y. (2017). Küresel rekabet endeksi göstergelerin küresel inovasyon üzerine etkisi. Business \& Management Studies: An International Journal, 5(4), 257-282.

Bayraktutan, Y., Tüylüoğlu, Ş., \& Özbilgin, M. (2012). Lojistik sektöründe yoğunlaşma analizi ve lojistik gelişmişlik endeksi. Uluslararası Alanya işsletme Fakültesi Dergisi, 4(3), 61-71.

Bekmezci, M., \& Aksungur, M. (2018). Lojistikte inovasyonun önemi. Toros Üniversitesi iisBF Sosyal Bilimler Dergisi, 5(9), 175-192.

Bilgiç, E., Türkmenoğlu, M. A., \& Koçak, A. (2020). Dijitalleşmenin lojistik yönetimi bağlamında incelenmesi. Bitlis Eren Üniversitesi Iktisadi ve Idari Bilimler Fakültesi Akademik Izdüşüm Dergisi, 5(1), 56-69.

Boscacci, F. (2013). L'innovazione logistica. Un'industria in formazione tra territorio, ambiente, e sistema economico. I fondamenti concettuali della Logistica, Aula, 1-5.

Burmaoğlu, S. (2012). Ulusal inovasyon göstergeleri ile ulusal lojistik perofrmansı arasındaki ilişki: AB ülkeleri üzerine bir araştırma. Ege Akademik Bakış, 12(2), 193-208.

Burmaoğlu, S., Kazançoğlu , Y., \& Şeşen, H. (2015). Lojistik sektöründe inovasyon belirleyicileri: Tedarik zincirinde ortak değer yaratma. EUL Journal of Social Sciences, 6(2), 37-58.

Cornell University, INSEAD, \& WIPO (2019). Global inovation index report.

Chieh, Y. L., \& Yi, H. H. (2007). Technological innovation for China's logistics industry. Journal of Technology Management \& Innovation, 2(4), 1-19.

Çubukçu, M., \& İmamoğlu, N. (2019). Lojistik performansın, firma performansı ve ihracat performansına etkisi. Uluslararası Sosyal Araştırmalar Dergisi, 12(62), 1221-1234.

Daugherty, P. J., Chen, H., \& Ferrin, B. G. (2011). Organizational structure and logistics sevice innovation. The International Journal of Logistics Management, 22(1), 26-51.

Duran, G., \& Türkoğlu, M. (2019). Lojistik sektörünün önemi ve bölgesel kalkınmaya etkileri. Uygulamalı Sosyal Bilimler ve Güzel Sanatlar Dergisi, 1(2), 86-97.

Elbert, R., \& Özsucu, Ö. (2012). Produkt- vs. prozessinnovation-produkt- vs. prozessinnovation ınnovationsmanagement. S. Wolfgang, \& T. C. Lieb içinde, Business Innovation in der Logistic. Wiesbaden: Springer Fachmedien, 5-37.

Erdal, H., \& Korucuk, S. (2018). Lojistik sektöründe inovasyon önceliklerinin belirlenmesi: Karşılaştırmalı bir analiz. Kocaeli Üniversitesi Sosyal Bilimler Dergisi, (36), 1-24.

Erdoğan, A. (2019). Türkiye'nin lojistik perofrmansı ve lojistik üslerin önemi. Akademik Sosyal Araştırmalar Dergisi, 7(99), 92-99.

Erenel, F., \& Kaya, H. (2018). Lojistik sektöründe farklı bir uygulama: Butik lojistik. First inTraders International Conference on International Trade Conference. İstanbul: Hiper Yayıncllık, 405-412.

Erkan, B. (2014). Türkiye'de lojistik sektörü ve rekabet gücü. Assam Uluslararası Hakemli Dergi, 1(1), 45-66.

Forte, E., D'Ambra, L., \& Siviero, L. (2012). Un Indicatore composito di valutazione dei potanziali di sviluppo logisticoeconomico del territorio: I'ındicatore acit. Associazione Italiana di Scienze Regionali XXXIII Conferenza Scientifica Annuale, Roma, 1-24. 
Fugate, B., Mentzer, J., \& Theodore, P. (2010). Logistic performans: Efficiency, effectiveness, and differation. Journal of Business Logistic, 31(1), 43-62.

Giunchiglia, F. (2013). Innovatione sociale la fuora frontiora. Department information engineering and computer science, DISI - Via Sommarive 5 - 38123 Povo. Trento: University of Trento.

Gök Kısa, C., \& Ayçin, E. (2019). OECD ülkelerinin lojistik performanslarının SWARA tabanlı EDAS yöntemi ile değerlendirilmesi. Çankırı Karatekin Üniversitesi iktisadi ve Idari Bilimler Fakültesi, 9(1), 301-325.

Griese, J., \& Sieber, P. (2000). Logistik in unternehmungsnetzwerken und virtuellen unternehmen. B. Kaluza, \& T. Blecker içinde, Produktions und Logistikmanagement in Virtuellen Unternehmen und Unternehmensnetzwerken. Berlin: Springer Verlag, 307-319.

Hagedoorn, J. (1996). Inovation and entrepreneurship: Shumpeter revisited. Industrial and Corparate Change, 5(3), 883896.

Hammer, O. H. (2009). Chancen und risiken des russischen logistikmarktes aus der sicht Deutschen logistikunternehmen. Hochschule Mittweida (FH) University of Applied Sciences University of Applied Sciences, Diplomarbeit. Leipzig.

Hancıoğlu, Y. (2016). Küresel inovasyon endeksini oluşturan inovasyon girdi ve çıktı göstergeleri arasındaki ilişkinin kanonik korelasyon ile incelenmesi: OECD örneği. AiBÜ Sosyal Bilimler Enstitüsü Dergisi, 16(4), 131-157.

Hassan, M., Shaukat, S., Nawaz, M., \& Naz, S. (2013). Effects of innovation types on firm performance: An empirical study on pakistan's manufacturing sector. Pakistan Journal of Commerce and Social Sciences, 7(2), $243-262$.

Ho, Y. H., Lin, C. Y., \& Chiang, S. H. (2009). Organizational determinants of green innovation implementation in the logistics industry. The International Journal of Organizational Innovation, 2(1), 3-12.

Horenshteyn, V. (2009). Chancen und risiken des Russischen logistikmarktes aus der sicht Deutschen logistikunternehmen. Hochschule Mittweida (FH) University of Applied Sciences Fachbereich Wirtschaftswissenschaften, Diplomarbeit. Leipzig.

INSEAD, (2007). The world's top Innovators. France: the World Business/INSEAD Global Innovation Index.

INSEAD, \& WIPO (2011). Global inovation index report (2011).

INSEAD, \& WIPO (2019). Global inovation index report (2019).

Jankowska, B., Matysek, A., Jedrych, K., \& Mroczek, D. (2017). Efficiency of national innovation systems-Poland and Bulgaria in the context of the global Innovation index. Comparative Economic Research, 20(3), 77-94.

Kalaycı, Ş. (2014). SPSS uygulamalı çok değişkenli istatistik teknikleri. Ankara: Anı Yayın Dağıtım.

Kernsten, W., Herstatt, C., von See, B., Kalogerakis, K., \& Wagenstetter, N. (2016). Schluss bericht zum projekt open inniovation in logistics. Hamburg: Bundesministerium.

Kersten, W., Seidel, A. V., \& Wagenstetter, N. (2012). Analyse und bewertung bestehender Innovationsmanagementmethoden für logistikdienstleistungsunternehmen. Industrie Management, 28(6), 31-34.

Kılıç, F. (2018). Açık inovasyon kavramı ve etkileri üzerine bir uygulama. Pamukkale Üniversitesi Sosyal Bilimler Enstitüsü İşletme Anabilim Dalı, Yayınlanmamış Yüksek Lisans Tezi, Denizli.

Lambert, D. M., \& Cook, R. L. (1990). Integrating marketing and logistics for increased profit. Business, 40(3), 22-29.

Lampe, K., \& Stölzle, W. (2012). State of the art von innovationen in der logistik. W. Stölzle, \& T. Lieb içinde, Business Innovation in der Logistik. Business Innovation Universität St. Gallen (Profilbereich Business Innovation). Wiesbaden: Springer Gabler.

Lucio, S. (2010). Economia dei transporti intermodali e innovatione logistica. Milano: Franco Angeli.

Mentzer, J. T., \& Firman, J. (1994). Logistics control systems in the 21st century. Business logistics, 15(1), $215-227$.

Mutlu, H. M., \& Ölmez, S. (2017). Lojistik performans ve ilişki kalitesi üzerine bir alanyazın incelemesi. Uluslararası Ticaret ve Ekonomi Araştırmaları Dergisi, 1(2), 99-120.

OECD, \& Eurostat (2005). Oslo klavuzu: Yenilik verilerinin toplanması ve yorumlanması için ilkeler. Ankara: TÜBITAK, 1117.

Olavarrieta, S., \& Ellinger, A. E. (1997). Resource-based theory and strategic logistics research. International Journal of Physica Distribution \& Logistics Management, 27(9), 557-589.

Pfohl, H. C. (2018). Logistiksysteme betriebswirtschaftliche grundlagen. Berlin: Springer-Verlag GmbH.

Pfohl, H., Köhler, H., \& Röth, C. (2008). Wert und innovationsorientierte Logistik - Beitrag des Logistikmanagements zum Unternehmenserfolg. H. Baumgarten içinde, Beste der Logistik, Berlin-Heidelberg: Springer. 
Porter, M., \& van der Linde, C. (1995). Toward a new conception of the environment-competitiveness relationship. Journal of Economic Perspectives, 9(4), 97-118.

Richey, G. (2005). The role of resource commitment and innovation in reverse logistics performance. International Journal of Physical Distribution \& Logistics Management, 35(4), 233-257.

Sauvage, T. (2003). The relationship between technology and logistics third-party providers. International Journal of Physical Distribution \& Logistics Management, 33(3), 236-253.

Schumpeter, J. (1934). The theory of economic development: An inquiry into profits, capital, credit, interest, and the business cycle. Harvard Economic Studies, 46.

Şıpoş, G. L., \& Bizoi, C. G. (2015). Innovation and logistic performance: Cause and effects. Revista Economica , 67(3), 112-127.

Taş, S. (2017). Inovasyon, eğitim ve küresel inovasyon endeksi. Bilge Uluslararası Sosyal Araştırmalar Dergisi, 1(1), 99123.

Taşel, F., Bayarçelik, E. B., \& Apak, S. (2019). Yenilik faktörlerinin analitik ağ sürecinde kullanarak önceliklendirilmesi. Beykoz Akademi Dergisi, (Özel Sayı), 64-85.

Ulutaş, A., \& Karaköy, Ç. (2019). G-20 Ülkelerinin lojistik performans endeksinin çok kriterli karar verme modeli ile ölçümü. Sivas Cumhuriyet Üniversitesi Iktisadi ve Idari Bilimler Fakültesi Dergisi, 20(2), 1-14.

Witkowski, K. (2017). Internet of things, big data, Industry 4.0 innovative solutions in logistics and supply chains management. Procedia Engineering, (182), 763-769.

Yalçınkaya, Y. (2010). Bilginin farkındalık ve farklılı̆ında organizasyonların gelecek alanı: İnovasyon. Türk Kütüphaneciliği Dergisi, 24(3), 373-403.

Yangınlar, G. (2019). Lojistik performans ile GSYH oranlarının türkiye ve G-7 ülkeleri arasında karşılaştırılması. V. Europan Congress on Economic Issues. Bakü: Pazıl Reklam Danışmanlık Matbaa ve Organizasyon, 68-80.

Yapraklı, T. Ş., \& Ünalan, M. (2017). Küresel lojistik performansı endeksi ve Türkiye'nin son 10 yıllık lojistik performansının analizi. Atatürk Üniversitesi Iktisadi ve Idari Bilimler Dergisi, 31(3), 589-606. 
This Page Intentionally Left Blank 